\title{
The Third Latin Recension of the Revelationes of Pseudo-Methodius - Introduction and Edition
}

This contribution aims, first and foremost, to enhance our understanding of one of the more prominent early medieval texts attributed to Methodius, the late antique bishop of Patara. An apocalyptic world history, written in Syriac in the late seventh century, was attributed to him. The text's main objective was to place the Islamic expansion in the East in the context of the history of salvation and it includes a prophetic section that runs up until the end of times. The Revelationes enjoyed instant success in the post-Roman world and were quickly translated into Greek and Latin. The latter version underwent a series of revisions early on, which led to several redactions being available by the ninth century. This article will mainly address the particular Latin redaction of the text which has been dubbed the "Third Recension" by modern scholars. It will offer a description of the context of its transmission, a summary of the contents and the first critical edition of the text. In order to understand the changes made by the redactor who produced this version, we need first to take a closer look at the genesis of the work in the Syrian East and at the first Latin version, which originated in the early eighth century.

\section{Pseudo-Methodius and the First Latin Recension [CGa]}

\subsection{Who was Pseudo-Methodius?}

First, we have to define what the Book of Revelations of Pseudo-Methodius is. The text is linked inseparably to the "Islamic" or "Arabic Expansion", which had an immense influence on the whole Eastern Roman Empire in the course of the seventh century CE. ${ }^{1}$ The Byzantine Empire lost two thirds of its territory and population and an even bigger part of its tax revenue between 634 and the middle of the cen-

1 See Donner, The Early Islamic Conquests.

Note: Cinzia Grifoni [CGr] wrote chapters 2, 3 and 5. Clemens Gantner [CGa] wrote chapters 1 and 4. Research for and writing of Cinzia Grifoni's contribution was funded by the SFB Visions of Community (Austrian Science Fund, FWF F 42-G 18)

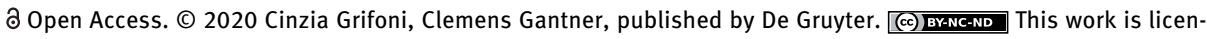
sed under the Creative Commons Attribution-NonCommercial-NoDerivatives 4.0 License.

https://doi.org/10.1515/10.1515/9783110597745-008 
tury. ${ }^{2}$ The impact of this expansion was at first less dramatic in the culturally Latin West, which was at the time quite far removed, both geographically and ideologically, from the events in the East. What quickly attracted attention in the West, however, was the constant flow of refugees from the former Roman provinces to the east and south. ${ }^{3}$ It was mainly in Italy and Sicily, the westernmost parts of the Roman Empire, that these people sought refuge. The debate about the Saracen, Hagarene or Ishmaelite "other" certainly got a new boost in the early eighth century, when the Iberian Peninsula was conquered (711-721) and Constantinople besieged (715717). ${ }^{4}$ Forays into Frankish territories, mainly Aquitaine (Toulouse 721) but also the north (Poitiers 732), had even more impact. Still, the available sources outside of Spain are actually very scarce and do not contain much information about the Saracens. ${ }^{5}$ While this, of course, does not mean that such sources never existed, ${ }^{6}$ the texts that have come down to us are mainly translations of, or, at least, largely based upon eastern originals. ${ }^{7}$ Of these, the most popular by far was an apocalyptic tractate in the guise of a history of the world, literally from its beginnings to its end - the Revelationes of Pseudo-Methodius (henceforth PsM). ${ }^{8}$ The original version, written in Syriac, was probably composed towards the end of a prolonged period of crisis and unrest, the so-called second Fitna (or Arab civil war, 680-692) ${ }^{9}$, although the work has been ascribed a number of different dates, all in the seventh century. ${ }^{10}$

2 See, for example, Donner, The Early Islamic Conquests; to get a good impression of just how big a shift had occurred in the old Roman East, see Haldon, The Palgrave Atlas of Byzantine History, 2932, and map 2.8.

3 See Gantner, "The Label 'Greeks' in the Papal Diplomatic Repertoire in the Eighth Century," 303349, on the situation in the city of Rome.

4 Saracens, Ishmaelites and Hagarenes were all used as terms describing Arab, Arabicised or Berber "others" in the time during and shortly after the Islamic Expansion, quasi synonyms. Ishmaelites and Hagarenes are both biblical terms referring to the story of Abraham and his handmaiden Hagar. See Tolan, Saracens.

5 See the relevant sections in Hoyland, Seeing Islam as Others Saw It; Tolan, Saracens.

6 Kedar, Crusade and Mission, 34.

7 Gantner, "Hoffnung in der Apokalypse?" 521-548.

8 Edition of the First Recension: Die Apokalypse des Pseudo-Methodius, ed. Aerts and Kortekaas, 64-199 (Latin/Greek); cited as: PsM, chapter, sub-chapter. See also the translation by Garstad, The Apocalypse of Pseudo-Methodius. On the Greek version, see also Brandes, "Endzeiterwartung im Jahre 1009 a. D.?" 301-320. For the Latin text, see also Sibyllinische Texte und Forschungen, ed. Sackur, 59-96. Edition of the Second Recension: "Eine frühe abendländische Aktualisierung der lateinischen Übersetzung des Pseudo-Methodius,” ed. Prinz, 6-17; cited as: PsM, R. II, line (consecutive count, not by page!). The Syriac original text has been masterfully edited in: Die syrische Apokalypse des Pseudo-Methodius, ed. Reinink.

9 Actually a series of more or less related conflicts the death of Caliph Mu'āwiyya; see Rotter, Die Umayyaden und der zweite Bürgerkrieg; especially on the later period relevant here, see Campbell, “'Abdallāh b. al-Zubayr."

10 See McGinn, Visions of the End, 70 and 301 (notes). Relevant for the present study is Prinz's dating of the work to 655, as this affected his dating of the Second Recension, see Prinz, "Eine frühe abendländische Aktualisierung der lateinischen Übersetzung des Pseudo-Methodius,” 1. Current 
This was a period when Eastern Christians suffered far more persecution and repression than under earlier Arab rule. ${ }^{11}$

The anonymous - or rather, pseudonymous - author of the Revelationes was a Christian living under Saracen rule. He must have spent a considerable part of his life in northern Mesopotamia (Iraq), as he used a lot of sources originating in the same area. ${ }^{12}$ It still remains unclear whether he actually worked on the text while living there. Neither do we know which branch of Christianity the author belonged to, as he fails to address any relevant matters of ongoing controversy. Melkites (orthodox Chalcedonians) and Monophysites dominated in the area and fought over issues of Christology where he was active, whereas the Nestorians (Church of the East) were certainly weaker. The sources he employs might make a Monophysite author more likely. ${ }^{13}$

The Revelationes were ascribed to Methodios, all of the earliest versions of the text bear his name. He was either bishop of Olympos or nearby Patara (both are given in hagiographical accounts) in Lycia in southern Asia Minor. In the Third Latin Recension of the text, he is constantly associated with the latter see, given as "Pytharensis". ${ }^{14}$ The prominent bishop had been martyred in $311^{15}$ in the course of the anti-Christian persecutions of the time and was widely recognised as a father of the Church on the basis of a few preserved tractates. There was not much information available on his life, however, which made him a good candidate for the authorship, and it is quite probable that the Revelationes were designed to carry this false ascription from the beginning on, given the work's prophetical outlook from the fourth century onwards.

The Revelationes present themselves as a history of the world. They follow a peculiar scheme of millennia and "weeks of years", meaning one seven-year bundle after another. The focus of the text is the lot of the Christians under Ishmaelite, that is essentially Muslim, rule and their eventual triumph over it. The Revelationes pre-

research mainly follows the dating to 691 proposed by Gerrit J. Reinink, the editor of the Syriac PsMtext, see Reinink, "Pseudo-Methodius und die Legende vom Römischen Endkaiser," 82-111, esp. 85; this view has also been accepted by some scholars who had previously favoured an earlier date of composition (e.g. McGinn, Antichrist, 90 and 307, n. 65).

11 Hoyland, Seeing Islam as Others Saw It, 263-264.

12 On the sources, especially the Syriac Cave of Treasures, see Aerts and Kortekaas, "Einleitung: Die Apokalypse des Pseudo-Methodius," 5-7; Sackur, "Einleitung: Pseudomethodius," 10-15. See also Reinink, "Der Verfassername 'Modios'," 46-64, at 51-60, and PsM syr., ed. Reinink, xxx-xxxi.

13 Reinink, PsM syr., xxvi-xxix, argues that the author was a Monophysite from northern Mesopotamia, whereas Hoyland, Seeing Islam as Others Saw It, 264, is more careful and thinks that a Melkite would be equally possible. On the different Christian groups in the area, see Troupeau, "Kirchen und Christen im muslimischen Orient," 391-472, esp. 399-452.

14 See edition in section 5 below.

15 Prinz, "Eine frühe abendländische Aktualisierung der lateinischen Übersetzung des PseudoMethodius," 2. Bracht, "Methodius von Olympus," 768-784, and Bracht, "Methodius of Olympus," $1-17$. 
dict that the Ishmaelites will rule ten of these year-weeks, a calculation which again points to the text having been drawn up towards the end of the seventh century. We have to note right away, however, that the Greek and Latin versions changed this to seven year-weeks, which makes the calculation of the date of composition problematic in these cases, but which fit the general tone and the parallelisation in play

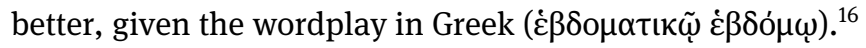

It is important to note that the biblicistic term "Ishmaelites" (Ismaelitae) is used for the Arabs or Muslims in the First Recension of PsM, just like in the text's Greek template. While the use of this biblical model (or the related "Agarenes") was not uncommon, ${ }^{17}$ it is significant in the context of the work's subsequent textual history, with the appearance of alternative terms such as Arabs or Saracens in later recensions being a good indicator that the redactor was deviating from the Latin original. ${ }^{18}$

\subsection{A Brief Overview of the Textual Transmission}

Originally composed in Syriac, the Revelationes were translated into Greek around 700, possibly in a Sinai monastery. This translation soon reached the Latin parts of Europe; its transmission was therefore surprisingly fast compared to other Greek or Syriac texts we can trace. ${ }^{19}$ Between 710 and 725 , the Latin translation was produced by a monk calling himself Peter (Petrus monachus) in an introductory letter (prefaciuncula), which sometimes accompanied the work in the textual transmission. ${ }^{20}$ It remains uncertain where the translation was made. Three of the four oldest manuscripts of this First Latin Recension are from Francia - nominally still Merovingian - whereas the fourth was produced in Italy, possibly Tuscany. ${ }^{21}$ Editors have tried to assign the Revelationes to several regions in Francia or to northern Italy, mainly using philological criteria. They do so on the basis that the oldest manuscripts are written in what is called "Merovingian Latin"22, a form of Latin incorporating a lot of rusticisms and signs of spoken post-classical Latin. It was also

16 Literally maybe the "sevenfold seven years" or "sevenfold weeks". See Hoyland, Seeing Islam as Others Saw It, 264 with n. 17, and Aerts and Kortekaas, "Einleitung: Die Apokalypse des PseudoMethodius," 6. See also PsM, XIII, 2. For the text, see PsM, ed. Sackur 59-60, trans. Garstad 74-77. 17 See Tolan, Saracens and Tolan, "A Wild Man, Whose Hand Will Be against All," 513-530.

18 See Gantner, "Hoffnung in der Apokalypse?," 534-536.

19 Aerts and Kortekaas, "Einleitung: Die Apokalypse des Pseudo-Methodius," 15-16. See Frenz, "Textkritische Untersuchungen zu 'Pseudo-Methodios'," 50-58, who still followed the earlier dating of the Syriac version.

20 Aerts and Kortekaas, "Einleitung: Die Apokalypse des Pseudo-Methodius," 28-31 and 57.

21 Aerts and Kortekaas, "Einleitung: Die Apokalypse des Pseudo-Methodius," 48-57.

22 Aerts and Kortekaas, "Einleitung: Die Apokalypse des Pseudo-Methodius," 21-25 and 28-31, esp. 29-30. 
to be found in Italy in the period in question. ${ }^{23}$ The manuscript transmission also fails to provide any definitive clues, as early medieval manuscripts were possibly more likely to have been preserved in early modern France than in Italy. ${ }^{24}$ The Latin translation of PsM coincides with the first phase of Saracen attacks on the southwestern European mainland, which witnessed the conquest of Spain (from 711), forays into Aquitania and Francia and attacks against the islands of the western Mediterranean. The vital threat for the remaining Roman ("Byzantine”) Empire began to be appreciated, especially in the wake of the second Arab siege of Constantinople between $717 / 18$, which may have been the event that triggered the wider distribution of the Greek PsM. PsM arrived in the Latin world in a climate that certainly greatly fostered immediate interest in the text. ${ }^{25}$ It is no wonder then that the Revelationes were instantly copied: the four oldest preserved manuscripts all belong to the eighth century itself, with the very oldest tentatively dated to $727 .{ }^{26}$ In total, over 220 manuscripts containing one of the four Latin recensions were produced throughout the Middle Ages. ${ }^{27}$ The most popular were certainly the first two Latin versions, of which the first is still present in about 50 codices, ${ }^{28}$ whereas the second, shortened and re-worked version is to be found in more than $150 .{ }^{29}$ In the latter, the Revelationes were adjusted to the interests of a Latin Western audience in a manner very similar, but not identical, to that characteristic of the Third Recension. ${ }^{30}$

PsM saw a big surge in its manuscript distribution in the eleventh century, probably because the apocalyptic outlook of the text made it relevant to the eschatological concerns aroused by the millennium. ${ }^{31}$ Largely due to its anti-Saracen main strand, it also remained popular in the time of the crusades. The "peoples of the north" (called just that in the First Recension, but Gog and Magog in later ver-

23 Frenz, "Textkritische Untersuchungen zu 'Pseudo-Methodios'," at 52-53, argues in that direction too; his idea that no one would have been able to translate Greek in Francia is to be discarded, though.

24 See, for example, Burigh, Medieval Manuscript Production in the Latin West.

25 Aerts and Kortekaas, "Einleitung: Die Apokalypse des Pseudo-Methodius," 3.

26 See Aerts and Kortekaas, "Einleitung: Die Apokalypse des Pseudo-Methodius,” 30, and esp. 5054, with n. 15, regarding the (shaky) dating of Ms Bern, Burgerbibliothek 611.

27 Aerts and Kortekaas, "Einleitung: Die Apokalypse des Pseudo-Methodius," 19. On the eighth century Latin renderings of the text, see also Herren, "The Revelationes of Pseudo-Methodius."

28 Aerts and Kortekaas, "Einleitung: Die Apokalypse des Pseudo-Methodius," 31.

29 Aerts and Kortekaas, "Einleitung: Die Apokalypse des Pseudo-Methodius," 32-33. There is great textual variance among the witnesses of the Second Recension, as the edition of Prinz, "Eine frühe abendländische Aktualisierung der lateinischen Übersetzung des Pseudo-Methodius,” clearly shows, even though the editor himself tried to downplay these differences. Still, all witnesses of the Second Recension go back to one crucial step of textual revision.

30 Prinz, "Eine frühe abendländische Aktualisierung der lateinischen Übersetzung des PseudoMethodius," 3-4.

31 In fact, the biggest share of the textual witnesses attributed to the Second Recension date to that period. See, for example, Lerner, "Millennialism," 332. On Millennialism in Europe around the year 1000, but also disconnected from it, see Landes, Heaven on Earth, 62-88. 
sions) mentioned towards the end of the text would in turn be interpreted as the Mongols/Tatars, and the Revelationes were also used as propaganda against the Ottoman Empire at the end of the Middle Ages. ${ }^{32}$ PsM was included in manuscript compendia dealing with the End Times from early on - one of the textual witnesses of the Third Recension, Karlsruhe, Badische Landesbibliothek, Augiensis Cod. perg. $254(\boldsymbol{A})$, will illustrate this below. ${ }^{33}$ On top of the work's own distribution, the Revelationes are likely to have influenced other Latin eschatological writings. The very successful tractate on the Antichrist by Adso of Montier-en-Der is often given as a case in point, despite not containing any direct citations from PsM. ${ }^{34}$

\subsection{Summary of the First Latin Recension ${ }^{35}$}

The chapter numbers follow the ones established in the edition of the Greek text by Anastasios Lolos. ${ }^{36}$

Ch. 1-2: deal with the creation, the times of Adam and Cain. Special emphasis is laid on the latter and his offspring, who are specifically blamed for having indulged in fornication (a topic that fascinated the author).

Ch. 3-5.1: the actions of Noah after the Flood and the birth of his fourth (!) son, Jonitus, a special character otherwise only found in apocryphal Syrian texts. He is presented as wise and learned and is associated with the absolute east, the country of the rising sun. The fate of the descendants of Noah, the establishment of kingdoms, the subsequent wars between them and the invasion of Sampsisano are also mentioned.

Ch. 5.2-5.9: a first invasion of the civilised world by the sons of Ishmael (prefiguring what is to come later); the invaders are vanquished by Gideon, and it is pronounced that they will invade for a second time and in turn be defeated by the Romans.

Ch. 6-7: kings of Babylon, the Medes and Persians

Ch. 8: Alexander and the imprisonment of the "Unclean Nations" (of the north). Alexander is presented as the son of a Macedonian king and an Ethiopian princess; he thereby prefigures the internationality of the later Christian empire. ${ }^{37} \mathrm{He}$ is also,

\footnotetext{
32 Aerts and Kortekaas, "Einleitung: Die Apokalypse des Pseudo-Methodius," 34-35, and Brandes, "Endzeiterwartung im Jahre 1009 a.D.?," 309, with n. 32.

33 See sections 3-5 below.

34 Rauh, Das Bild des Antichrist im Mittelalter, 152, and on Adso 153-164.

35 The summary is based on Garstad (trans.), Pseudo-Methodius xiv-xvi.

36 Pseudo-Methodius, Die Apokalypse, ed. Lolos.

37 This also shows in ch. 14,5.
} 
as is often the case in Christian and even Islamic texts, presented as one of the audience's own, as a proto-Christian in this case. ${ }^{38}$

Ch. 9: after Alexander's death, Byzas marries Chouseth, Alexander's mother. Their daughter, Byzantia, is in turn married to Romulus Armelaus. Their sons then rule Rome, Byzantium and Alexandria respectively. We have an alternative rendering of Roman history here, drawing upon Syrian material.

Ch. 10: prophecy and reflection concerning the kingdom of the Romans/Christians.

Ch. 10.6-11.18: second invasion of the sons of Ishmael (10.6-11.3), caused by sexual sins of the Christians (11.4-8); the countries invaded by Ishmaelites (11.913); the depredations of the Ishmaelites (11.14-18).

Ch. 12: the falling away of Christians. This is a central concern of the author, oftentimes overlooked. He sees apostates and opportunists going over to Islam as the biggest danger for Christianity - this was one of his main messages to his audience and one that certainly also had a timeless quality.

Ch. 13.1-6: suffering under the Ishmaelites will separate the faithful from the unfaithful; the Ishmaelites taunt the Christians. [After this section, the Greek version has an interpolated prophecy concerning the second Arab siege of Constantinople.]

Ch. 13.11-18: defeat of the Ishmaelites by the king of the Romans, peace and restoration of the devastated lands. This is another very central section, as it contains the element of hope, maybe the most important factor in the remarkable success of the text. ${ }^{39}$

Ch. 13.19-21: invasion of the "Unclean Nations" (here not indentified as Gog and Magog!), who are defeated by the Christians; the king of the Romans goes to Jerusalem. When compared to the long account of the Ishmaelites, the shortness of this section gives it the air of an appendix.

Ch. 14: assumption of the cross, death of the king of the Romans; the son of perdition (note: not called the Antichrist) rises, and many are deceived by his signs and wonders. He is then refuted by Enoch and Elijah. The Second Coming of Christ follows, i.e. the Final Judgment of all souls and the end of time.

38 For more information on the use of Alexander in PsM, see Möhring, Der Weltkaiser der Endzeit, 83-84.

39 See Gantner, "Hoffnung in der Apokalypse?” 


\section{The Third Recension: Manuscript transmission [CGr]}

Now that we have given an overview of the original Latin version, we can dive into the manuscript transmission of the Third Recension; this information is essential in order to understand the context in which the text circulated and the reasons behind its inclusion in the different manuscripts. In chapter 3 we will proceed to describe and interpret its contents.



Fig. 1: Incipit of the Third Recension in MS Karlsruhe, Badische Landesbibliothek, Aug. perg. 254, fol. 204 r (Source: Badische Landesbibliothek) 
In a contribution from 1988, Marc Laureys and Daniel Verhelts offered a first survey of 196 manuscripts transmitting the text of PsM in its various Latin versions. They distinguished four different recensions of the work, the first of which consisted, as we have seen above, of the first translation of Pseudo-Methodius' work from Greek into Latin, while the further three contained various adaptations of it, each unrelated to the others. Laureys and Verhelts listed a provisional number of witnesses for each of the four versions of the text. According to this survey, which was - as the authors themselves admitted - incomplete, the Second Recension was the most widespread in the Middle Ages, whereas the Third Recension, traced only to the late-eighth-century Karlsruhe, Badische Landesbibliothek, Augiensis Cod. perg. 254, fols. 204r-211r, evidently enjoyed far less success. ${ }^{40}$

Ten years later, W.J. Aerts and G.A.A. Kortekaas published a critical edition of the First Latin Recension..$^{41}$ In their introduction, the editors stated that the number of the witnesses of PsM in its various Latin recensions had risen to c. 220. However, they did not specify which manuscripts exactly could be added to the already known list. ${ }^{42}$ As for the Third Recension, in particular, the editors mentioned that "few manuscripts" transmitted it, but they neither provided a list of the codices they referred to nor explained exactly how many witnesses they were able to add to the single one Laureys and Verhelts had recorded ten years before. ${ }^{43}$

In his recently published monograph on the early medieval understanding and reuse of the apocalyptic tradition, James Palmer dedicated an entire chapter to Pseudo-Methodius' work and its reception in the medieval West. ${ }^{44}$ In this, he also paid attention to the Third Latin Recension, describing some major differences from the text of the First. Moreover, he gave account of a further witness of the Third Recension, namely the manuscript Cologne, Dombibliothek, Cod. 15, fols. 84v-86r, written around the middle of the ninth century. ${ }^{45}$

To these two witnesses of Pseudo-Methodius' Third Recension can now be added a third, namely St Gall, Stiftsbibliothek, Cod. 238, pp. 385-392, where the text was written in its entirety by the local monk Winithar around $760 .{ }^{46}$ Apart from

40 Laureys and Verhelst, "Pseudo-Methodius, Revelationes," 112-136. The Karlsruhe manuscript of the Third Recension is recorded on page 129.

41 Aerts and Kortekaas, "Einleitung: Die Apokalypse des Pseudo-Methodius."

42 Aerts and Kortekaas, "Einleitung: Die Apokalypse des Pseudo-Methodius," 19: "Weitere Untersuchungen unsererseits mit Hilfe rezenter Kataloge in den Universitätsbibliotheken von Leiden und Groningen bieten Grund für die Registration von \pm 220 Handschriften, neben vielen Übersetzungen in den Volkssprachen.”

43 Aerts and Kortekaas, "Einleitung: Die Apokalypse des Pseudo-Methodius,” 32, n. 55: "Das Verbreitungsgebiet der 3. Rezension ist, wenn man die wenigen Handschriften in Betracht nimmt, beschränkt geblieben."

44 Palmer, The Apocalypse in the Early Middle Ages, 107-129.

45 Palmer, The Apocalypse in the Early Middle Ages, 123, n. 72.

46 Grifoni, “A New Witness of the Third Recension of Ps.-Methodius’ Revelationes,” 446-460. 
three exceptions, to which I will return below, the text copied - and adapted - by Winithar was homogenous with that transmitted by the other two witnesses.

Hence, the Third Latin Recension has thus far been discovered in three manuscripts dating back to the end of the eighth and to the ninth centuries. Certainly, further witnesses are still waiting to be detected, but for the moment, relying on these three codices, we can attempt a first description of the context of transmission.

\subsection{Karlsruhe, Badische Landesbibliothek, Augiensis Cod. perg. 254}

Karlsruhe, Badische Landesbibliothek, Augiensis Cod. perg. 254, which I will refer to hereafter and in the edition as $\boldsymbol{A}$, became part of the early medieval library of Reichenau, one of the most important monastic centres and scriptoria of the time, in the course of the tenth century at the latest. Since this codex has only rarely caught the attention of modern scholars, I will first describe its structure and contents and then concentrate on the place occupied by the Third Recension in it.

$\boldsymbol{A}$ contains three different codicological units. ${ }^{47}$ The first, consisting of folios 171, transmits an anonymous seventh-century treatise on the Gospels of Irish origin, which circulated on the Continent under the name of Gregory or Jerome. ${ }^{48}$ According to Bernhard Bischoff, the treatise was copied by several writers in an unidentified scriptorium, possibly in the western part of modern-day Germany, during the first third of the ninth century. ${ }^{49}$

At this same centre and in the same period the treatise was bound together with quires of external origin, which now form the second and third codicological units of $\boldsymbol{A}$. These contain extracts from Isidore's De ecclesiasticis officiis (fols. 72r-152r) ${ }^{50}$ and a homiletic collection (fols. 153r-211r) respectively, written in a pre-Caroline mi-

47 The manuscript is described in: Holder, Die Reichenauer Handschriften, 573-579. It is included as item n. 1110 in Lowe, Codices Latini Antiquiores, hereafter CLA (for a digitised version, see https:// elmss.nuigalway.ie/catalogue/1577 - accessed 4 February, 2018). See furthermore Bischoff, Katalog der festländischen Handschriften, 364 n. 1735; Laureys and Verhelst, "Pseudo-Methodius, Revelationes," 129. The manuscript is available in digitised form under: https://digital.blb-karlsruhe.de/ urn/urn:nbn:de:bsz:31-1487 (accessed 4 February, 2018).

48 The treatise is edited in PL 30, cols. 531-590. It is recorded under the title Expositio IV evangeliorum, recensio I in Lapidge and Sharpe, A Bibliography of Celtic-Latin Literature 400-1200, no. B341, to which I refer for further bibliography.

49 Bischoff, Katalog der festländischen Handschriften 1, no. 1734.

50 Isidore of Seville, De ecclesiasticis officiis, ed. Lawson. Here, on page 26 of the introduction, the editor gives account of the omissions and abridgements characterising the Isidorian text contained in $\boldsymbol{A}$. 
nuscule..$^{51}$ Both these texts were copied between the eighth and ninth centuries in the same scriptorium. Here, moreover, a contemporary local hand added an Orologium at the end of the homiletic collection, i.e. a guide to determining the hour of the day all across the year according to the length of the shadow cast by the gnomon in a sundial (fols. 211v-212r). To establish where exactly this scriptorium was located is a difficult task and would require a thorough palaeographic comparison, which has not been undertaken to date. The catalogue of the Reichenau manuscripts preserved at Karlsruhe, published by Alfred Holder in 1906, provides no information regarding the place of origin of the quires we are dealing with. ${ }^{52}$ The issue of their origin was first broached in Elias A. Lowe's Codices Latini Antiquiores, where the writing of both the Isidorian extracts and the homiletic collection was attributed to a northern Italian or a Swiss centre. ${ }^{53} \mathrm{~A}$ few years later, Bernhard Bischoff placed the origin of both texts in northern Italy, pointing out some striking similarities with a contemporary manuscript written at Novara, namely Novara, Biblioteca Capitolare, Cod. 2 (LXXXIV). ${ }^{54}$ Subsequent, rare mentions of the second and third codicological units of $\boldsymbol{A}$ rely on the suggestions of either Lowe or Bischoff, without engaging in a new, more detailed palaeographical analysis. ${ }^{55}$ As for the contents of both units, they do not offer any specific clues that might help to determine their place of origin with more certainty. Therefore, pending a more precise analysis of their script, we will stick to the assumption that these texts were written either in northern Italy or in some Swiss scriptorium.

Soon after they had been penned, the Isidorian extracts, the homiletic collection and the Orologium reached the centre that Bischoff tentatively placed somewhere in modern-day western Germany. Here, they were bound together with the anonymous treatise on the Gospels mentioned above to form a single volume. At this stage, one of the copyists of the treatise added a litany on folios $212 \mathrm{v}-213 \mathrm{v}$, filling the folios left blank at the end of the last quire of $\boldsymbol{A}$. After having addressed a conspicuous list of both male and female saints asking for support, the litany ends with a direct prayer to God. In this, the writer invokes divine mercy, peace and security from enemies' attacks upon God's people (populus tuus). Moreover, he prays for the life and military success of both Emperor Louis the Pious (r. 814-840) and the

51 A detailed palaeographic analysis of this minuscule is still lacking. In particular, it has not been determined how many copyists cooperated in writing the two units. Bischoff, Katalog der festländischen Handschriften 1, no. 1735 describes the minuscule as a "bewegte, ligaturenreiche Minuskel von mehreren Händen”.

52 Holder, Die Reichenauer Handschriften, 573-574.

53 CLA VIII 1110.

54 Bischoff, Katalog der festländischen Handschriften, no. 1735. Two folios of the Novara manuscript are partly reproduced in CLA III 406.

55 Laureys and Verhelst, "Pseudo-Methodius, Revelationes," 129 follow Lowe's interpretation; Palmer, The Apocalypse in the Early Middle Ages, 123 follows Bischoff. 
Frankish army. ${ }^{56}$ Louis the Pious is the subject of a further addition, which was written onto folio $1 \mathrm{r}$ in the tenth century, i.e. after the three parts now forming $\boldsymbol{A}$ had already been bound together. ${ }^{57}$ In question is an annalistic annotation, which apparently occurs only in $\boldsymbol{A}$ and which carries in red the title Incipit numerus annorum. In 1839, Georg Pertz published this text alongside a further annalistic notice from another Reichenau manuscript under the label of Annales Augienses brevissimi ${ }^{58}$ It consists of a sixteen-line entry, copied over an erasure, which focuses on the year $832 \mathrm{AD}$. Seven of the nine sentences forming the entry refer to that year, which is mentioned three times in correlation with Louis' rule. 832 is namely stated twice to be the eighteenth year of Louis' kingship and once as the nineteenth year of Louis' imperial command. ${ }^{59}$ This focus on Louis the Pious matches the contents of the final litany. I would assume, therefore, that the annalistic notice was copied on purpose onto folio $1 \mathrm{r}$ in the tenth century after the former, now illegible, content of the page had been erased. However, it seems probable that the notice had been originally written soon after 832, since the interest in this year, whatever the reason, seems improbable for the tenth century. As for its place of origin, I would posit the Ala-

56 A, fol. 213v: Propitius esto, parce nobis domine. Ab omni malo libera. Ab hoste malo libera. A morbo malo libera. Ab incursu malo libera. Ab ira tua libera. Ab omnibus aeternis suppliciis. Ab ira ventura libera. Per crucem tuam libera. Peccatores te rogamus. Vt pacem donis te rogamus. Vt sanitatem nobis donis. Vt ludoico himperator<em> vel exercitum francorum conservare digneris. Vt eis vitam et victoriam donis te rogamus. Vt iram vel indignationem tuam a populo tuo averteris digneris [sic!]. Vt indulgentiam peccatorum nobis donis te rogamus. Vt vitam perpetuam nobis tribuas te rogamus. This transcription differs slightly from that provided by Holder, Die Reichenauer Handschriften, 578. For a study on intercessory prayers for rulers in the Carolingian period, see Choy, Intercessory Prayer and the Monastic Ideal in the Time of the Carolingian Reforms, 131-160.

57 For the dating to the tenth century, see Bischoff, Katalog der festländischen Handschriften 1, no. 1734. Holder, Die Reichenauer Handschriften, 573, seems to date the very writing of this addition to the year 832 by reason of its content. Two further additions dating to the tenth century are found among the final leaves of the book, i.e. a Runic alphabet on fol. 211 and a lexicological gloss on fol. $213 \mathrm{v}$, right at the end of the litany.

58 Annales Augienses Brevissimi, ed. Pertz, 136-137. I reproduce the entry contained in $\boldsymbol{A}$ as published in ibid., 136, n. 1: Incipit numerus annorum. Sunt anni ab initio mundi secundum Iheronimum usque ad incarnationem Domini 3957. De nativitate Domini usque ad Hludowici regis annum 18mum sunt anni 832. Insimul iuncti sunt faciunt annos 4789. Sunt anni, ut septuaginta interpretibus habetur ab origine mundi usque ad Christum 5199. A nativitate Christi usque ad annum 19mum Hludowici imperatoris sunt anni 832. Hos insimul iunge faciunt annos 6031. A morte Gotofredi duces (sic!) Alamannorum sunt anni 123. A grando et duro hieme numerantur anni 68 usque 18mum annum Hludowici regis. De subiugatione Italiae regionis computantur anni 58.

59 The distinction made here between Louis' titles is remarkable. With regard to the year 832, Louis is presented as an emperor who has reigned for nineteen years (i.e. since 813). This makes sense considering the fact that his father, Charlemagne, had appointed him as co-emperor in 813 exactly. Concerning the title of rex, however, Louis had already been a king since 781, when he was anointed as rex Aquitanorum by Pope Hadrian I in Rome. He is recorded as such in the documentary evidence, although rarely, as shown in: Wolfram, Intitulatio, 220-224. Therefore, I would assume that this notice refers to Louis' adoption of Charlemagne's title of rex Francorum et Langobardorum after his father's death in 814 . 
mannic region and probably the Reichenau scriptorium. The third-last sentence of the text affirms namely that 832 was the one hundred and twenty-third year since the death of Gotfrid, the dux Alamannorum. ${ }^{60}$ The cultivation of the memory of Gotfrid (d. 709) long after his death would make most sense in a region such as Carolingian Alemannia, in which his offspring were still politically active.

Summing up the information gathered so far, we can state that the three parts forming the manuscript $\boldsymbol{A}$, as we know it today, were put together probably under Louis' rule at a Carolingian scriptorium possibly located in western Germany. ${ }^{61}$ Here, a treatise on the Gospels copied locally was bound together with two works coming from the same northern-Italian or Swiss scriptorium to form a single manuscript, which was enriched with intercessory prayers for Emperor Louis the Pious. It can be speculated that soon after, and at the latest in the tenth century, $\boldsymbol{A}$ reached the library of Reichenau, where an earlier annalistic notice also focusing on Emperor Louis was copied over an erasure on its first folio.

In this miscellany, the Third Recension of PsM (fols. 204r-211r) concludes the homiletic collection of twenty items contained in the third codicogical unit of $\boldsymbol{A}$. Just a glimpse at the titles introducing both the collection in its entirety and some of the texts helps us to understand that the early medieval compiler perceived and presented all these items as sermons. Firstly, the title appended to the whole collection on fol. $153 \mathrm{r}$ reads: Incipit collectario (sic!) de diversis sententiis. Thus, the twenty texts are altogether described as sententiae, that is as authoritative precepts expressing the truth. ${ }^{62}$ Furthermore, five of the items are introduced straightforwardly as homilies (homilia); on one occasion the homily is improperly ascribed to Augustine. ${ }^{63}$ Finally, a long title in red marks the beginning of the Revelationes with the words: Incipit dicta sancti Methodii Pytharensis episcopus de regna regum et de novissimis temporibus certa demonstratio (see fig. 1). ${ }^{64}$ The Revelationes too were regarded as a sermon written by Methodius, the bishop of Patara. They are described as "assertions (dicta) concerning the rule of kings and the unerring description of the last times". In these, therefore, both earthly sway (regna regum) and eschatolog-

60 For Gotfrid (d. 709), see Zettler, Geschichte des Herzogtums Schwaben, 48-54 and Geuenich, Geschichte der Alemannen, 103-107.

61 A thorough palaeographic analysis of the pre-Caroline minuscule of both the first part of $\boldsymbol{A}$ and of the litany is still lacking. For the moment, the vague indication of origin ("Westdeutschland?") given by Bischoff, Katalog der festländischen Handschriften, no. 1734, cannot be narrowed down. Comparing the first part of $\boldsymbol{A}$ with the manuscripts produced at Reichenau in the first third of the ninth century, I would, in any case, exclude that it was written there.

62 On the meanings of the term sententia in Antiquity and the Middle Ages, see the recent contribution by Codoñer, "La «Sententia» y las «Sententiae» de Isidoro de Sevilla," 3-48, esp. 3-10.

63 See entry no. 18 in the following table. Augustine is also regarded as the author of entry no. 3. 64 The title introducing the Third Recension in $\boldsymbol{A}$ reproduces the title of the First Recension almost faithfully. See Aerts and Kortekaas, "Einleitung: Die Apokalypse des Pseudo-Methodius," 71: Incipit sancti Methodii episcopi Paterensis sermo de regnum gentium et in novissimis temporibus certa demonstratio. 
ical visions formed the main focus of the narrative. As we are now going to see, it was exactly because of this latter topic that the Revelationes were included in the homiletic collection of $\boldsymbol{A}$.

For the sake of clarity, the following table records briefly the main contents and sources, when known, of the twenty items forming the homiletic collection contained in $\boldsymbol{A}$ :

Tab. 1: The homiletic collection of $\boldsymbol{A}$ (fols. $153 \mathrm{r}-211 \mathrm{r})^{65}$

\begin{tabular}{lll}
\hline 1 fols. 153r-156r & No title \\
& Inc.: Christus ait diligite invicem [...] Expl.: iniquitate et iniustitia. \\
& Source: unknown, but of supposed Irish origin (Clavis Patrum Latinorum, \\
& hereafter CPL, 790). \\
& Content: virtues and vices, perspective of eternal reward for the righteous. \\
& No title \\
& Inc.: Omnis roris [...] Expl.: in diem resurrectionis in secula seculorum. \\
& Source: unknown, but of supposed Irish origin (CPL 791). ${ }^{66}$ \\
& Content: description of the afterlife penance of the soul in the third, fourth, \\
& sixth and seventh heavens. Admonition to righteous conduct, addressed \\
& also to bishops and priests (voe sacerdotis qui acceperunt populum et non \\
& predicantes eis evangelium regni). \\
& Title: Sanctus Augustinus episcopus dixit. \\
& Inc.: Fratres karissimi qui in Christo [...] Expl.: in letitia magna. \\
& Source: unknown, but of supposed Irish origin (CPL 792). ${ }^{67}$ \\
& Content: virtues and vices, perspective of eternal reward or punishment. \\
& Description of the catastrophic events announcing Christ's Second Coming.
\end{tabular}

65 The first six texts on the list have been published in Fragments retrouvés d'apocryphes priscillianistes, ed. De Bruyne, 318-335. De Bruyne considered them to bear witness to the survival of Priscillianist ideas in the medieval West. Later scholars challenged his arguments, instead considering these and most of the other texts contained in the homiletic collection of $\boldsymbol{A}$ as evidence of the influence of Irish biblical exegesis on the Continent. See, for instance, James, "Irish Apocrypha," 916; Bischoff, "Wendepunkte in der Geschichte der lateinischen Exegese im Frühmittelalter," 205273, at 230; McNally, Der irische Liber de numeris, 38-39, 59, 65, 106, 109, 115, 122; Smyth, "The Irish Liber de Numeris," 291-297; Wright, The Irish Tradition in Old English Literature, 64-69. The Brepols Clavis Patrum Latinorum (CPL) gives eight-century Ireland as the origin of the first six texts (In Hibernia conflata, et quidem saec. VIII, nec originis est Priscillianisticae, CPL 790-795). Lapidge and Sharpe, Bibliography, 331-332, no. 1252, consider these works to be of possible or arguable Celtic origin and list them among the Dubia.

66 See James, "Irish Apocrypha," 15-16.

67 The Clavis Patristica Pseudoepigraphorum Medii Aevi (CPPM), vol. 1A, ed. Machielsen, records this pseudo-Augustinian sermon as item no. 2351 on 531. A passage from it, which is edited in Fragments retrouvés d'apocryphes priscillianistes, ed. De Bruyne, 324, 1. 10-19, recurs with the same wording in the Sermo de symbolo et virtutibus, ed. Keefe, 6-8, esp. 1. 27-46. 
4 fols. 160r-161v Title: Homilia de die iudicii.

Inc.: Oportit enim nos [...] Expl.: et angelis in regno celorum.

Source: unknown, but of supposed Irish origin (CPL 793).

Content: admonition to be righteous in consideration of the Last Judgment. Description of earthly punishments for the sinner. Concluding picture of monks and virgins rejoicing and singing along with God's saints and angels in heaven.

5 fols. 162r-165v Title: De parabolis Salomonis filii David.

Inc.: Timor domini gloria [...] Expl.: erunt sicut angeli dei.

Source: unknown, but of supposed Irish origin (CPL 794).

Content: a sermon filled with biblical echoes, both canonical and apocryphal. One direct address to the audience (Ideo fratres karissimi et omnes populus qui audit me sine intermissione orate dominum). Rewards and punishments according to one's behaviour. Exhortation to all to give alms and to kings and judges to act in observance of God's precepts. The seven virtues, which, like steps in a ladder, lead to salvation; the seven ways to redeem the soul; the world's twelve major abuses; the three acts leading humans to hell or to heaven, the three acts which cannot be forgiven by God. ${ }^{68}$

6 fols. $165 \mathrm{v}-172 \mathrm{v}$ Title: Liber “canon in ebreica” Hieronimi presbyteri.

Inc.: Canon in ebreica [...] Expl.: habeat vitam aeternam.

Source: unknown, but of supposed Irish origin (CPL 795). ${ }^{69}$

Content: exhortation to follow God's precepts supported by several biblical or apocryphal quotations. The audience is addressed once with the same words as in the previous sermon (Ideo fratres karissimi et omnes populus...).

7 fols. $172 \mathrm{v}-174 \mathrm{v}$ Title: De reddendis decimis et primitivis.

Inc.: Primus homo qui dedit decimam [...] Expl.: omnibus insidiis diabuli cui gloria in saecula saeculorum amen.

Source: unknown.

Content: exhortation to offer tithes, first fruits and alms in order to both avoid God's punishment and gain treasure in heaven.

68 This long sermon, edited by Fragments retrouvés d'apocryphes priscillianistes, ed. De Bruyne, 328-330, shows similarities with several other texts of Irish origin. Lines $80-85$ of De Bruyne's edition reproduce verbatim the beginning of the seventh-century Irish treatise De duodecim abusivis saeculi, which is ascribed here in $\boldsymbol{A}$ to Gregory the Great: see Pseudo-Cyprian, De xii abusiuis saeculi, ed. Hellmann, 32, 1. 2-6. Moreover, lines 92-100 of De Bruyne’s edition recur in a further sermon of supposed Irish origin published in McNally, "In nomine dei summi," 142, 1-10. In general, the arrangement of arguments into lists of seven (heptads) or three items (triads), which occurs here on five occasions, seems typical of the Hiberno-Latin exegetical tradition (see McNally, "In nomine dei summi,” 132).

69 Heptads and triads occur in this sermon too. In particular, it features the seven seals of the Revelation of John and the seven gifts of the Holy Spirit (see McNally, Der irische Liber de numeris, 108-109 and 117-118). 
8 fols. $175 r-180 r \quad$ No title

Inc.: Rogo vos et admoneo [...] Expl.: sub sua protectione producat, qui cum patre et spiritu sancto vivit et regnat in saecula saeculorum.

Source: Caesarius of Arles, Sermo 199 in its entirety. ${ }^{70}$

Content: exhortation to fast and, most of all, to offer alms to the poor during Lent.

9 fols. 180r-181v Title: Homilia de die iudicii.

Inc.: Fratres karissimi quam timendus [...] Expl.: eripere dignetur qui cum patre et spiritu sancto vivit et regnat in secula seculorum.

Source: unknown. ${ }^{71}$

Content: apocalyptic end of the world by fire and Last Judgment.

10 fols. $181 \mathrm{v}-185 \mathrm{v}$ Title: Homilia in die sanctum pasche.

Inc.: $O$ fratres dilectissimi praesentem [...] Expl.: in vitam aeternam in secula seculorum amen.

Source: unknown. ${ }^{72}$

Content: exhortation to distinguish conduct that pleases God from bad behaviour on the occasion of Easter Sunday. List of vices to be avoided for entering heaven. Special address to bishops and priests with regard to the vice of vainglory (Maxime in nobis sacerdotibus viget). Detailed description of Last Judgment resting on the account from Matthew's Gospel.

11 fols. $185 v-187 v$ Title: Epistola de exitu anime.

Inc.: Primun quidem docit nos [...] Expl.: iusti autem in vitam aeternam amen.

Source: unknown, but of supposed Irish origin. ${ }^{73}$

Content: right after death the soul will form a bone of contention between white angels and black demons. Description of both the tortures awaiting the soul destined for the demons and the joy awaiting that destined for the angels.

70 Caesarius of Arles, Sermones, ed. Morin. For Sermon 199, see CCSL 104, 803-807.

71 This sermon has not yet been published. Morin records it, but does not ascribe it to Caesarius of Arles (see Caesarius of Arles, Sermones, ed. Morin, CCSL 104, 978). As for its sources, a short passage at the bottom of fol. 181r reproduces Isidore's Synonyma; see Isidore of Seville, Synonyma, ed. Elfassi, 41, 489-498. The apocalyptic devastation by fire accompanying Christ's Second Coming, and in particular the mention that seas will dry out (mare siccatur), recurs in sermon no. 3 of the table.

72 This sermon has not yet been published. Germain Morin considers it to be too barbaric to originate with Caesarius of Arles (see Caesarius of Arles, Sermones, ed. Morin, CCSL 104, 978: Barbarae aetatis barbarus fetus, qui nihil ad rem nostram attinet). Some passages recur in both sermons no. 3 and no. 9 of the table and in the Irish text called Catechesis Celtica (see McNally, "In nomine dei summi," 129).

73 This sermon is almost the same as that which Robert McNally published and attributed to an Irish scholar (McNally, “In nomine dei summi,” 134-136). 
12 fols. 188r-191v Title: Homilia de eo quod scriptum est in evangelio, bonus homo de bono thesauro cordis sui profert bona.

Inc.: Audivimus fratres karissimi [...] Expl.: sub sua protectione perducat qui vivit et regnat in saecula saeculorum amen.

Source: Caesarius of Arles, Sermo 160 in its entirety. ${ }^{74}$

Content: Christ dwells in the heart of the righteous, whereas the devil inhabits the heart of the wicked. Humans can choose whom they want to harbour. Their choice will apply to their afterlife too. List of the moral virtues and of the good deeds which make Christ want to stay in one's heart, thus ensuring eternal reward.

13 fols. 191v-192v Title: De camara Christi homini dei.

Inc.: Fundamentum ipsius camarae [...] Expl.: inveniat in nobis talem mansionem. qui vivit et regnat in secula seculorum.

Source: unknown. ${ }^{75}$

Content: the good Christian is compared metaphorically to a room (camara) in which Christ would like to dwell. Twenty-four virtues feature as the room's constitutive elements. A further fifteen spiritual virtues perform specific tasks in the room and guarantee its correct maintenance.

14 fols. 193r-193v No title

Inc.: Septem scala sunt quibus ascenduntur [...] Expl.: sic suffocatur iustitia Source: unknown. ${ }^{76}$

Content: like in item 5: the seven virtues, which, like steps in a ladder, lead to salvation; the seven ways to redeem the soul; the world's twelve major abuses. ${ }^{77}$

15 fols. 193v-194r Title: Incipit de ebrietate [...] Incipit de subrietate.

Inc.: Ebrietas autem [...] Expl: sine honorem facit; Inc.: Subrietas vero [...]

Expl: hominem constabiliscit.

Source: Pseudo-Isidore, Testimonia patrum (CPL 385). ${ }^{78}$

Content: the dangers of drunkenness and the corresponding advantages of sobriety.

74 Caesarius of Arles, Sermones, ed. Morin, CCSL 104, 655-657.

75 This is a text which circulated mostly under the fictitious name of Jerome. It is recorded in the CPPM, ed. Machielsen, vol. 1A, no. 979. See also Bibliotheca Hieronymiana Manuscripta, ed. Lambert, vol. 3B, no. 523.

76 See above, n. 68, with regard to the seventh-century Irish treatise De duodecim abusivis saeculi as well as to heptads and triads.

77 Here, like in sermon no. 5 of the table, the twelve abuses (De duodecim abusivis saeculi) are ascribed to Gregory the Great. A headline written in uncial, but with the same ink as in the surrounding text, introduces the text: Sanctus Gregorius papa dixit. The text itself begins with the red initial "H" (Haec sunt que in hoc seculo [...], fol. 193r, 16).

78 Pseudo-Isidore, Testimonia patrum, ed. Lehner, 124-125 (chapters 10, 1. 10-19 and 1. 1-9). See also Pseudo-Isidore, Liber de numeris, 1298D-1299B and McNally, Der irische Liber de numeris, 4344. The beginning of the second passage on sobriety with the adverb vero as adversative particle (subrietas vero...) and the strict contraposition to the argumentation developed in the previous passage on drunkenness demonstrate that the two texts were conceived as a single unit. Hence, I have recorded them as a single item in the table. 
16 fols. 194r-195r Title: Incipit de septenario expleto.

Inc.: Quare dixit propheta septem sunt oculi dei [...] Expl: propterea dicti sunt oculi dei qui praevident omnem terram.

Source: cf. Pseudo-Bede, De septem donis Spiritus Sancti. ${ }^{79}$

Content: the allegorical meaning of the number seven in Zach. 4:10 is explained by referring to the seven spirits of Isaiah 11:2 and to the seven biblical patriarchs.

17 fols. $195 \mathrm{r}$-196r Title: De modis penitentiae et reconciliationem.

Inc.: Romani reconciliant hominem [...] Expl.: tantum det in elimosina.

Source: the penitential decisions partly recur in already edited collections of Insular origin. 80

Content: short compendium of conflicting precepts regarding form and duration of penance.

18 fols. 196r-201r Title: Homilia sancti Augustini.

Inc.: Rogo vos fratres karissimi adtentius cogitemus [...] Expl: et vos feliciter pervenitis ad regnum, praestante domino nostro lesu Christo cui est honor et gloria in saecula saeculorum amen.

Source: Caesarius of Arles, Sermo 103 in its entirety. ${ }^{81}$

Content: exhortation to be a Christian not only in name but also by virtue of good deeds like righteous and incorruptible behaviour, almsgiving, prayers. Enumeration of several good Christian deeds and virtues. Exhortation to abandon pagan practices like shouting to the new moon, worshipping trees or springs, refraining from work on Thursday in honour of Jupiter.

19 fols. $201 v-204 \mathrm{r}$ Title: Incipit casticatio ad populum.

Inc.: Fratres dilectissimi gratias ago quod in sanctis festivitatibus ... Expl.: implere posse quod predicamus prestante domino nostro lesu Christo cui est honor et gloria in saecula saeculorum amen.

Source: Caesarius of Arles, Sermo 55, abridged and adapted. ${ }^{82}$

Content: abuses concerning the attendance of Church on feast days. Plea against corruption in judging. Perspective of reward and punishment in the afterlife according to present behaviour. Final accusation against negligent priests.

79 Pseudo-Bede, De septem donis Spiritus Sancti, 553B-C. The text, suitably called incipit de septenario expleto, aims at explaining the meaning of the number seven in the biblical verse of Zacharias 4:10 (septem isti oculi Domini qui discurrunt in universa terra). The mention of the seven spirits of Isaiah 11:2 and of the seven biblical patriarchs introduces the quote from Pseudo-Bede, in which both these references occur again. McNally supposes that this sort of explanation originated under the influence of Irish exegesis: see McNally, Der irische Liber de numeris, 108-109.

80 This short penitential collection has not been edited thus far. The initial part (fol. 195r, 9-15) recurs in the Poenitentiale Theodori, U I, 13, ed. Finsterwalder, 306. It deals with the differences between Greek and Roman use concerning the public reconciliation of penitents, as explained by Meens, Penance in Medieval Europe 600-1200, 93-94. A further short passage (fol. 195v, 1-4) recurs in chapter 14 of the De paenitentia attributed to Gildas and edited in MGH, Auctores Antiquissimi 13, ed. Mommsen, p. 90. I could not identify the source of the following passage, in which Theodore of Canterbury is explicitly mentioned (Theodorus conlaudabit, fol. 195v, 4-12). The concluding part of the text (fol. 195v, 12-196r, 2) recurs in the Liber Sacramentorum Augustodunensis, ed. Heming, rubric 2304, 1. 1-5.

81 Caesarius of Arles, Sermones, ed. Morin, CCSL 103, 64-68. 
20 fols. 204r-211r Title: Incipit dicta sancti Methodii Pytharensis episcopus de regna regum et de novissimis temporibus certa demonstratio.

Inc.: Igitur Adam et Eva ... Expl.: et regnabunt cum Christo in saecula saeculorum amen.

Source: Pseudo-Methodius, Revelationes, Third Latin Recension.

Content: see below.

As the table shows, the homiletic collection of $\boldsymbol{A}$ consists of either complete homilies or preparatory texts for preaching in which the afterlife perspective is predominant. ${ }^{83}$ The items are mostly anonymous, at times incorrectly ascribed to patristic authorities such as Augustine, Jerome or Gregory the Great. ${ }^{84}$ Four out of the twenty texts are genuine homilies by Caesarius of Arles, which, however, never disclose his authorship in their titles. ${ }^{85}$ Many of the items recorded in the table share contents with works of supposed insular or, more specifically, Irish origin. This would imply that the compiler of our collection either worked in a centre preserving insular exegetical output along with Caesarius' homilies and the Revelationes, or simply reproduced a model in which these works featured together already. As for the contents of the collection, both the internal recurrence of specific topics and the logical succession of some of the texts lead me to think that they were gathered according to a precise plan. Indeed, the various items generally share the aim of showing which virtues assure the humans of a place in heaven after death. They engage primarily with the topic of heavenly reward and infernal punishment according to right or bad behaviour on earth. A further main concern occurring in some of them is penance, i.e. what should sinners do in order to both atone for guilt before God and to deserve a blessed and joyous afterlife. In particular, almsgiving features very often as the privileged tool for expiating one's minor sins. ${ }^{86}$ The four homilies by Caesarius of Arles, one of the sixth-century "preachers of repentance," ${ }^{87}$ fit perfectly well in this context. Finally, the depiction of the Last Judgment, in which the good will receive their everlasting reward and the bad their eternal retribution, occurs in five texts and features, most notably, in the dramatic conclusion of the Revelationes

82 Caesarius of Arles, Sermones, ed. Morin, CCSL 103, 240-247. The succession of topics of Caesarius' homily has been rearranged; chapter 4 on drunkenness has been dropped.

83 See McNally, "In nomine dei summi” for a similar homiletic collection, in which some of the texts gathered cannot be considered as proper sermons, but rather as documents providing "themes and a certain amount of authentic inspiration for preaching" (123).

84 See entries no. 3, 6, and 18 in the table.

85 See entries no. 8, 12, 18, and 19 in the table. Note that the title of entry no. 18 ascribes the homily to Augustine.

86 See, in particular, entries no. 5, 7, 8, 17, and 18 in the table. On the perception of sins as debts toward God and on the expiatory function of almsgiving, see Brown, The Ransom of the Soul, 83114.

87 Brown, The Ransom of the Soul, 137. 
in their Third Recension. ${ }^{88}$ As we shall see below, the final part of the Third Recension contains several elements of novelty compared to the First. Indeed, it mentions firstly the various catastrophic events preceding Christ's coming (drought, famine etc.), secondly the appearance of Christ's cross in the sky, and finally the destruction of the world by fire. All these topics are absent from the conclusion of the First Recension, whereas they recur, remarkably, in homilies n. 3, 9 and 10 of the collection. ${ }^{89}$ Due to such similarities, the Third Recension offers a very coherent ending to the booklet.

Altogether, the collection contained in $\boldsymbol{A}$ can be considered as a homiletic tool for priests focusing on the moral preparation for the Last Judgment and on the salvation of the soul. The compendium envisages God's people in its entirety as audience. Indeed, it addresses not only the laity but also, in some passages, bishops and priests. Item n. 2 rebukes, for instance, those sacerdotes who did not accomplish their duty of preaching the gospel. Item n. 10 warns them against the vice of vainglory, "which concerns us especially" (maxime in nobis sacerdotibus viget). Finally, item n. 19 reproduces Caesarius of Arles' admonishment of negligent priests. In such context, the Third Recension of PsM offers both a coherent and a spectacular conclusion, in which the earthly fight between good and evil, that began with Adam and his offspring, finds its end in the apocalyptic devastation of the world by fire and in the Second Coming of Christ to judge all human souls.

\subsection{St. Gallen, Stiftsbibliothek, Cod. 238}

St. Gallen, Stiftsbibliothek, Cod. 238, which I will call $\boldsymbol{S}$ hereafter and in the edition, is probably the oldest known witness of the Third Recension of PsM. Since I have dealt with the contents of this manuscript in a previous contribution, I will limit myself to stressing only some major characteristics on this occasion..$^{90} \boldsymbol{S}$ was written by the monk and priest Winithar at St Gall, where he had come around 760 in the wake of the newly appointed abbot, Johannes (r. 759-782)..$^{91}$ The very peculiar traits of Winithar's hand recur in at least seven further manuscripts preserved in the St Gall library, which he wrote either in their entirety or in collaboration with other copyists. ${ }^{92}$ As for the first group of autographs, they contain not only copies of or extracts

\footnotetext{
88 See entries no. 3, 4, 9, 10, 11 and 20 in the table.

89 See n. 72.

90 See Grifoni, “A New Witness of the Third Recension of Ps.-Methodius' Revelationes.”

91 On Winithar's biography and autographic production, see Ochsenbein, "Sonderling im Galluskloster: Winitharius," and, more recently, Walter Berschin and Bernhard Zeller, "Winithar in Sankt Gallen.”

92 St. Gallen, Stiftsbibliothek, Codd. 70 and 907, as well as the fragment 1399a2, are regarded as Winithar's autographs in their entirety, whereas St. Gallen, Stiftsbibliothek, Codd. 2, 11, 109 and 225 were written by him only in part. In her recent monograph on the origin and dissemination of Ale-
} 
from previous literature but also texts which Winithar claims to have composed on his own. This is the case, for instance, with the so-called Versus Winitharii (p. 250258 ) in St. Gallen, Stiftsbibliothek, Cod. 70 and with the proplema Winitharii (p. 178-181) in $\boldsymbol{S} .^{93}$ As for the other group of manuscripts, which Winithar wrote only in part, they were completed according to Winithar's directives. Indeed, either he wrote the initial lines of specific texts before passing the pen on to other scribes, or he added titles, chapter divisions and, at times, corrections after the copying had been completed. ${ }^{94}$ Altogether, thus, Winithar can be regarded as the designer and the person responsible for the production of all these codices, which now offer significant evidence of the cultural interests that moved him.

Not surprisingly, the Bible and its interpretation formed the major focus of Winithar's activity. Firstly, several of his manuscripts transmit single books of the Bible, or parts of them, accompanied by various exegetical tools, be they treatises, homilies, genealogies or summaries of biblical content organised in question-andanswer form. Secondly, a significant portion of his compendia deals with the meaning of words, i.e. with etymology and lexicography. For instance, two of his manuscripts, namely $\boldsymbol{S}$ and St. Gallen, Stiftsbibliothek, Cod. 907, contain very substantial glossaries, in which Winithar combined previous glossographic material with information drawn from Isidore's Etymologiae to form a new linguistic tool. ${ }^{95}$ St. Gallen, Stiftsbibliothek, Cod. 225 also bears witness to Winithar's lexicographic interest, transmitting Isidore's Differentiae verborum and parts of Eucherius' Instructiones, a work which also closes the collection of texts transmitted by $\mathbf{S}$. Finally, computus, chronology and various works on moral issues are well represented throughout Winithar's compendia.

The texts contained in $\boldsymbol{S}$ reflect such interests to a great extent. In my opinion, their succession in the book is not accidental, but responds rather to a specific plan. I see in $\boldsymbol{S}$ a sort of encyclopaedia, in which Winithar summarised firstly the biblical account of human history, secondly the physical properties of the world and finally

mannic minuscule Natalie Maag describes in detail the traits of Winithar's hand and includes St. Gallen, Stiftsbibliothek, Cod. 194 in the group of his autographs. Furthermore, Maag bestows on Winithar the role of leader of the scriptorium; see Maag, Alemannische Minuskel, 36-54. Also, Veronika von Büren ascribes to Winithar the copying of Pseudo-Methodius' Revelationes in their Second Recension in Zürich, Zentralbibliothek, Cod. C 65, fols. 80v-88v; see von Büren, "Le «De natura rerum» de Winithar,” 395. Except for the fragment St. Gallen, Stiftsbibliothek, 1399a2 (CLA VII 996), Winithar's manuscripts and the corresponding catalogue descriptions are available online under: http://www.e-codices.unifr.ch/de/list/csg (accessed 4 February, 2018).

93 The Versus Winitharii transmit a moral exhortation addressed by Winithar to his confrères (see Berschin and Zeller, "Winithar in Sankt Gallen"); the proplema Winitharii consists of a succinct explanation of the Pentateuch in question-and-answer form (see Grifoni, "A New Witness of the Third Recension of Ps.-Methodius' Revelationes," 450-451).

94 Maag, Alemannische Minuskel, 43-44.

95 For the contents of Winithar's manuscripts and, in particular, for his lexicographic output, see McKitterick, "Le pouvoir des mots," 30-43. 
the characteristics of specific peoples as well as, more generally, the ideal conduct of human beings. Furthermore, he framed this corpus of texts with linguistic tools, which open and conclude the book. The audience for such an endeavour was probably limited to the local community at St Gall, for which Winithar had created a reference book of all-embracing content. ${ }^{96}$ Indeed, after the huge glossary mentioned above (p. 1-163), $\boldsymbol{S}$ transmits résumés of the main contents of the Bible and of some exegetical issues concerning the Octateuch in question-and-answer form (pp. 163304). A small section dedicated to chronological issues follows, which recapitulates the history of humankind from Adam to Jesus (p. 305-312). Afterwards Winithar's focus shifts to the description of physical phenomena, which involves reproducing Isidore's De natura rerum with the addition of a short extract from the first book of Vergil's Georgica (pp. 312-385). ${ }^{97}$ At this point the subject changes again and peoples come to the fore. With the aid of two texts (pp. 385-396), which he both entitled De gentibus, Winithar addressed respectively the issues of the place occupied by peoples in the Christian history of salvation and of the ethnic classification of the inhabitants of what we now would call Western Europe. The first text he used is the Third Recension of PsM (pp. 385-392), the second consists of extracts from Isidore's Etymologiae 9.2 (pp. 392-396), which Winithar reshuffled in order to describe first of all the Romans and then other "Western-European" gentes (i.e. Goths, Lombards, Germanic peoples in general, Suevi, Burgundians, Saxons, Franks, Britons, Scotti, Gauls and Vascones/Basques). A section dedicated to Christian moral instructions follows: here we find both a text called De moribus, which is ascribed in the title to the ancient philosopher Seneca, and Gennadius' De ecclesiasticis dogmatibus (pp. 396-434). In the final part of the manuscript, Winithar began again to summarise the main contents and exegetical problems of the Bible from the point where he had left off, inserting a résumé in question-and-answer form of the four Books of Kings as well as prologues to each of the major and minor Prophets. $\boldsymbol{S}$ closes with a linguistic tool, namely the second book of Eucherius' Instructiones, which Winithar reproduced almost in its entirety.

This brief description of the contents of $\boldsymbol{S}$ shows that the Third Recension of PsM was copied here in a context completely different from that of $\boldsymbol{A}$. In my opinion, Winithar chose to include the Third Recension in the Christian encyclopaedia he was producing not by reason of its moral or eschatological contents but primarily because it pays special attention to peoples, bestowing on some of them a particular role in the history of Christianity. The leading position assigned to the "Romans of Rome" until the end of the world, as we shall see below, might correspond to Wini-

96 The presence in $\boldsymbol{S}$ of four sentences in which Winithar presents himself as the author of two texts contained in the manuscript and addresses the reader (omnis enim qui legerit, 181), asking for prayers, proves that an external audience was envisaged for $\mathbf{S}$ rather than it being (only) designed for personal use; see Grifoni, "A New Witness of the Third Recension of Ps.-Methodius' Revelationes," 446-448.

97 Grifoni, “A New Witness of the Third Recension of Ps.-Methodius' Revelationes,” 453. 
thar's own vision of the hierarchy of peoples in human history. This impression is reinforced by the passages from Isidore's Etymologiae which he copied right after the Third Recension and also entitled De gentibus. Indeed, Winithar adjusted the original succession of the Isidorian passages to place the Romans in an outstanding position and at the head of the remaining Western gentes.

On a final note, I would like to remark that Winithar knew PsM in two, perhaps even in three, different versions. Along with the Third Recension, which he adapted and copied in his own hand in $\boldsymbol{S}$, he certainly also knew the First Latin Recension. Indeed, St. Gallen, Stiftsbibliothek, Cod. 225, which was compiled under Winithar's supervision, ${ }^{98}$ transmits the First Latin Recension on pp. 384-439. ${ }^{99}$ According to Veronika von Büren, moreover, Zürich, Zentralbibliothek, Cod. C 65, which contains the Revelationes in the Second Recension (fols. 80v-88v), is also written in Winithar's own hand. Von Büren's attribution is disputed, however. In the first place, it is the subject of controversy whether the Zürich manuscript was produced in the scriptorium of St Gall in Winithar's time at all. ${ }^{100}$ Be that as it may, Winithar certainly had both the First and the Third Recension at his disposal when he designed his manuscripts. He chose to copy the latter in order to talk about peoples and to stress the outstanding position of the Romans, and, in particular, of those Romans directly associated with the city of Rome.

\subsection{Köln, Erzbischöfliche Diözesan- und Dombibliothek, Cod. 15.}

Köln, Erzbischöfliche Diözesan- und Dombibliothek, Cod. 15, which I will refer to as $\boldsymbol{K}$ hereafter and in the edition, was written at an unidentified scriptorium within the borders of modern-day Germany in the course of the ninth century. ${ }^{101}$ Two main scribes participated in the production of the book. The first wrote the major bulk of the pages, copying almost a third of the Expositio libri comitis by Smaragdus of

98 CLA VII 928.

99 Laureys and Verhelst, "Pseudo-Methodius, Revelationes," 117, no. 27. A study of the relationship between this manuscript and $\boldsymbol{S}$ concerning the text of the Revelationes is a desideratum.

100 See n. 92 above. The manuscript has not been digitised yet. It is recorded in CLA VII 1017, which suggests an Alamannic origin ("Written in the Alemannic area, hardly in an important centre”). Mohlberg, Katalog, 38, no. 95, does not specify, whether the manuscript was written in St Gall or rather belonged to St Gall before moving to Zürich ("8 Jahrh. [...] Aus St. Gallen"). See also Laureys and Verhelst, "Pseudo-Methodius, Revelationes," 128, no. 134. Maag, Alemannische Minuskel does not list the Zürich manuscript under Winithar's output.

101 The manuscript is available in digitised form at http://www.ceec.uni-koeln.de (accessed 4 February, 2018). Here it is linked to the description from Anderson and Black, The Medieval Manuscripts of the Cologne Cathedral Library, in the revised digital version from 1997. Anderson and Black date the manuscript to the first third of the ninth century. A further catalogue record, however, dates the production of $\boldsymbol{K}$ to the second half of the ninth century; see Gattermann, Handschriftencensus Rheinland, vol. 1, 583-584. 
Saint-Mihiel (fols. $1 \mathrm{v}-81 \mathrm{v}$ ). ${ }^{102}$ This text ends suddenly on fol. $81 \mathrm{v}$ with the letters glofor gloriam. This abrupt cessation was caused by the loss of the central folios of quire 11 , of which only the two external folios remain $(81 \mathrm{r}-82 \mathrm{v})$. It is impossible to know at what point the first scribe stopped writing. He certainly copied only a part of the Expositio, perhaps on purpose. It seems that the second scribe took his work up exactly on the final folio of quire 11 (fol. 82r), probably after the central folios of the quire had already been lost. Here he copied a brief, anonymous commentary on the Gospels (fol. 82r-v). Then he employed three more quires (until fol. 100v) to accommodate a further nineteen short texts of mainly homiletic nature, which deal with various topics. Some of them convey allegoric or moral explanations of biblical passages; others contain, for instance, brief accounts of the origin of the world or the creation of Adam. A further group of texts focuses on moral matters, providing biblical models for several Christian virtues, condemning vices or again exhorting to penance. A final cluster addresses liturgical or computistic issues. ${ }^{103}$ Every single item is provided with a title, which, in the majority of the cases, offers a clue as to the content, or, more rarely, declares a pseudo-epigraphic paternity for the texts. Augustine is mentioned thrice as author, while the names of the late antique Church authorities John Chrysostom, Anthony, Jerome and Methodius occur once each. Determining the sources of these texts is a complex task, which I could not pursue on this occasion. ${ }^{104}$ As far as I can judge, however, the compendium lacks the coherence of contents that characterises the homiletic collection of $\boldsymbol{A}$.

The Third Recension of PsM features on folios $84 \mathrm{v}-86 \mathrm{r}$. It is framed by a brief pseudo-Augustinian sermon providing an allegorical interpretation of the parable of the ten coins (Luke 15:8-10) and by a sermon on penance ascribed to John Chrysostom in the title. ${ }^{105}$ Neither text contains an eschatological perspective nor a relevant thematic affinity with the Third Recension. This, in turn, is introduced by the corrupt title De Daniel in libro metotii patnis (= paternis?) esaię, which is probably an inaccurate rendering of De Daniel in libro Methodii Paterensis [or Patarensis] ecclesiae ("Concerning Daniel in the Book by Methodius from the Church of Patara"). As is typical of the collection, the title provides clues as to the content that follows. Thus, the whole Third Recension is presented here as an interpretation of the biblical Book of Daniel, to which the text does indeed refer explicitly in the course of the

102 For Smaragdus' Expositio, also known as Collectiones in epistolas et evangelia, see Rädle, Studien zu Smaragd von Saint-Mihiel, 113-194. The work is published in PL 102, cols. 13C-552D. The text contained in $\boldsymbol{K}$ reaches until col. 167D.

103 I refer to Anderson and Black's catalogue for a more detailed description of the contents of this section. A thorough analysis of the sources of the single items is still lacking.

104 To the description provided by Anderson and Black I can only add that the sermon contained on fols. $83 \mathrm{r}-84 \mathrm{r}$ and entitled Sermo ex lectione euuangelii is an almost verbatim reproduction of homily 37 of the second book of Gregory's Homiliae in Evangelia, encompassing paragraphs 8 to 10 of the modern edition: Gregory the Great, Homiliae in Evangelia, ed. Étaix, 354-358.

105 The two sermons carry respectively the titles: Incipit dicta sancti augustini episcopi de decem talenta (fol. 84r) and Incipt sermo sancti Iohannis de penitenciam dicens (fol. 86r). 
narrative, where mention is made of the vision of the four Persian kings contained in Daniel 11. Furthermore, the title contains the traditional, pseudo-epigraphic attribution to Methodius, whose affiliation to the city of Patara was, however, misread and inaccurately copied either by the scribe of $\boldsymbol{K}$ himself or at some earlier point in the textual transmission. The text of the Third Recension contained in $\boldsymbol{K}$ features several unintentional omissions of text-segments ending with the same word as the last one copied (so-called "saut du même au même"), and generally offers a more deficient version compared to the other two witnesses. Although the manuscript was produced in the course of the ninth century, its orthography, morphology and syntax do not show significant traces of the linguistic accuracy being pursued by Carolingian intellectual elites at the same time.

In conclusion, the survey of the context of transmission of the Third Recension in the three known witnesses shows that each redactor saw a different focus in the text and included it accordingly in his miscellany. The redactor of $\boldsymbol{A}$ chose the Third Recension as the perfect conclusion to his homiletic collection, in which the afterlife perspective and the depiction of the events accompanying Christ's Second Coming were predominant. The similarities in content between the final part of the Third Recension - which differs slightly from that of the First, as we shall see in the following section - and several passages occurring in the corpus of this collection are particularly striking. Could it be that the Third Recension too originated in an environment influenced by Irish or Insular exegesis, as many of the other texts in $\boldsymbol{A}$ apparently did? The redactor of $\boldsymbol{S}$, the presbyter Winithar of St Gall, used the Third Recension as a prophetic account on specific peoples and their role in human history. Finally, the compiler of the collection of texts contained in the second part of $\boldsymbol{K}$ presented the work as an exegetic tool for the interpretation of the biblical Book of Daniel.

\section{The Contents of the Third Recension [CGr]}

The Third Recension is both an abridgement and an adaptation of the First Recension. It was apparently produced soon after the First began to circulate and was already available to Winithar around 760 . With rare exceptions, the three known witnesses transmit a homogeneous text, which summarises heavily the contents of ten of the fourteen chapters into which modern editors have arranged the First Recension. ${ }^{106}$ The contents of chapters 4, 6, 7, and 12 of the First Recension do not recur in the Third at all.

106 For the modern edition of the First Recension see above, n. 8; for the English translation see n. 35. 
The historical part of the Revelationes, embracing chapters 1 to 9 of the First Recension, went through major modifications in the Third, particularly in the text copied, or rather personally readapted, by Winithar. Its initial part abridges the account of biblical history from the expulsion of Adam and Eve from Paradise to the deeds of Noah's sons, especially those of Jonitus (chapters 1 to 3 of the First Recension). Indeed, the Third Recension contains only a concise enumeration of Adam's descendants and a cursory mention of both Noah and the Flood. The names of Shem, Ham and Japheth feature only once and only in $\boldsymbol{A}$, whereas the account on Noah's fourth son, Jonitus, maintains most of its original length. After this, the Third Recension integrates passages taken from both Isidore's Chronicon (4.1) and Etymologiae (5.39.5-8 and 9.2.6). ${ }^{107}$ These responded to the aim of presenting the progeny of Shem, and consequently the birth of Abraham and of his offspring, instead of the progeny of Ham described by the First Recension in the ensuing fourth chapter. In particular, the Third Recension recalls explicitly via Isidore that Ishmael was born from Abraham by his Egyptian concubine Hagar and that Ishmael's descendants, that is to say the Ishmaelites, are called Saracens through a corruption of the original name. Moreover, the Third Recension stresses that the Saracens are a cruel and powerful people (gens crudelis et valida) that lives in the desert. Winithar's version, as transmitted by $\boldsymbol{S}$, shows a further peculiarity in this section: in contrast to the other two witnesses, $\boldsymbol{S}$ alone omits the account of Noah and his son Jonitus, who is not mentioned in the Book of Genesis at all. In other words, $\boldsymbol{S}$ skips the résumés of chapters 2 and 3 of the First Recension as transmitted by both $\boldsymbol{A}$ and $\boldsymbol{K}$. Right after Adam's death, $\boldsymbol{S}$ presents the Isidorian account of the descendants of Shem until the birth of Abraham, beginning with Ragau (Gen. 11:20). I like to think that the absence of this text was not the result of Winithar's distraction in copying but rather an intentional omission, which reflects his preference for sticking with the narrative contained in the Book of Genesis. It could be, however, that this segment of text was actually missing from Winithar's exemplar.

Chapter 4 of the First Recension (the wars against the descendants of Ham) was skipped entirely by the redactor of the Third Recension, who instead proceeded to his depiction of the horrible Saracens, which draws on parts of chapter 5. Only two passages from this chapter recur in the Third Recension, i.e. the account of the attack against Western regions by the Ishmaelites and the prophecy about their ultimate defeat by the king of the Romans. Moreover, in reproducing these passages the Third Recension introduces substantial innovations. Firstly, the attack undertaken by the Ishmaelites is presented in a prophetic way, that is to say, as something that will happen in the very Last Days (in novissimis diebus). ${ }^{108}$ The First Recension, on the contrary, had described this offensive in chapter 5 both as a fact

107 See Isidore of Seville, Chronicon, ed. Martín, 4-208 (the link pages), at 8-9. For the Etymologiae, see Isidore of Seville, Etymologiarum sive Originum libri XX, ed. Lindsay.

108 See below the Editorial principles on p. 230 for a detailed description of the innovations introduced with regard to the tenses in this passage. 
that had already occurred in the past - once more in conflict with the information on the Ishmahelites contained in the Bible - and as a prophecy about the future, when the Ishmaelites will be defeated by the Christian kingdom of the Romans. Secondly, whereas the king of the Romans of the First Recension has to be interpreted as the Christian emperor of Byzantium, all three witnesses of the Third Recension state that the king of the Romans shall rise from the city of Rome (surgit rex Romanorum de Roma). After this the Third Recension skips to chapter 8, making no mention of the history of the kingdom of Babylon, which is narrated in chapters 6 and 7 of the First Recension. Chapter 8's account of Alexander's enclosure of the twenty-two "Unclean Nations" behind the bronze gates is reproduced almost literally and without remarkable omissions. Here again, however, $\boldsymbol{S}$ features a singularity compared to the other two witnesses. Indeed, the story of the confinement of the "Unclean Nations" ends in all three manuscripts with a biblical quote from Ezekiel predicting that the peoples of Gog and Magog, included among them, will invade the land of Israel on the last day (Ezek. 38:14-16). A list naming all the imprisoned peoples closes the chapter. ${ }^{109}$ At this point $\mathbf{S}$ alone includes a sentence stating that both the Book of Daniel and the Book of Revelation confirm the prophecy of this invasion. ${ }^{110}$ The remark was probably conceived and added by Winithar himself, who interrupted the narration on purpose to offer further biblical parallels, thus enhancing the claims of the Revelationes to reliability. After this the text contains an abridgement of chapter 9 of the First Recension. In particular, it preserves the account of the progeny of Chouseth, the Ethiopian mother of Alexander the Great, who, after Alexander's death, married again, this time to Byzas, the king of Byzantium. The union of Chouset and Byzas' daughter Bizancia with Romillus/Romulus, the king of Rome, bound the Romans tightly to the Ethiopians. This proves particularly significant when considering the prophecy contained in Psalms 67:32, "Ethiopia shall soon stretch out her hands to God", which recurs several times across both the First and the Third Recensions. ${ }^{111}$ Thanks to their mutual bond, the prophecy could be applied to the Romans as well as to the Ethiopians. Thus, both the First and the Third Recensions explain the meaning of the biblical verse by relating it to the kingdom of the Romans, which will be the last to exist on earth before the advent of the Antichrist and the final demise of the world. ${ }^{112}$ As we have seen, however, the Third Recension refers to a king of Western Romans, whereas the First alludes to the Byzantines. At this point all three witnesses of the Third Recension

109 The names of the twenty-two "Unclean Nations" are only in part homogeneously recorded in the three witnesses of the Third Recension. The names of Gog and Magog, however, open the list in each manuscript.

110 Et hęc sentenciam danihelis profetia adprobat et apocalipsis iohannis apostoli testimonium dat (cf. edition, 1. 102). See Daniel 11 and Revelation 20:7-10.

111 On Chouset's progeny and the interpretation of Psalms 67.32, see Reinink, "Pseudo-Methodius und die Legende," 82-111, esp. 99-101 and 111.

112 Cf. Eusebius of Caesarea, Historia ecclesiastica, 2.1.14., ed. Schwartz and Mommsen. 
add a sentence that again bring the Saracens to the fore as the ultimate rivals of the Romans. By recalling directly the passages which had readapted chapter 5 , the Third Recension reiterates that the kingdom of the Romans shall emerge to defeat the sons of Ishmael, defend the Christian realm and subjugate the Saracens under a terrible yoke. ${ }^{113}$

From the prophetic part of the First Recension (chapters 10 to 14) the Third adopts only those elements that allow the narrative to straightforwardly reach the apocalyptic end. In particular, the Third Recension summarises only the very last part of chapter 10, evokes remotely a few sentences of chapter 11 and skips completely chapter 12 . Of the two final chapters only chapter 14 is reproduced with fidelity, whereas chapter 13 is heavily abridged. The primary focus of the Third Recension is the future clash between Saracens and Romans. Many details concerning the Saracen invasions and wicked domination are omitted. For instance, we find no mention of the numerous lands subjugated by the Ishmaelites, nor does the description of their rule feature the horrific scenes occurring in the First Recension. Although their invasion is explained as a punishment for the sins of the Christians in both texts, the Third Recension lacks the explicit statements of the First and dedicates only half a sentence to the topic. The Saracens' coming is introduced abruptly: their wickedness shall arise in the seventh millennium (ascendit malitia Sarracinorum in septimo tempore), causing death and destruction until the kingdom of the Romans will defeat them definitively, bringing back peace and serenity among the Christians. The following invasion of the "Unclean Nations" (gentes inmundas) receives but a brief mention, and their defeat by one of God's commanders is not described at all. A second point of focus of the Third Recension is the appearance of "the Son of Perdition, that is to say of the Antichrist", as the text specifies. ${ }^{114} \boldsymbol{S}$ and $\boldsymbol{K}$ present him as the son of a virgin, whereas $\boldsymbol{A}$ sticks to the First Recension's depiction of the Antichrist as the son of a woman and a man belonging to the tribe of Dan. The final part of the narrative abridges only slightly the text of chapter 14 of the First Recension, keeping the theatrical death of the king of the Romans, the account of the wonders accomplished by the Antichrist and the death of the two servants of God Enoch and Elijah, who had dared to rebuke him. At this point, for the third time, S (fols. 392-393) presents a peculiarity in comparison to the other two witnesses. Here the narrative flow is interrupted by a long quotation from Revelation 11:3-13 concerning the two prophets Enoch and Elijah just mentioned in the text. The biblical quote is introduced by the red uncial title In Apocalipsin and closed by explicit de Apocalipsin et incipit de priora leccione, again in red uncial characters. In this case I am also persuaded that the addition should be ascribed to

113 Vnde erit regnum Romanorum, qui subiciet filios Ismahel et uincet eos et defendet regnum Christianorum et subiugauit (sic!) iugo pessimo Sarracinos (cf. edition, 1. 113-115).

114 Et tunc ueniet filius perditionis, hoc est Antichristus (cf. edition, 1. 145-146). 
Winithar himself, who was again pursuing his aim of linking the Third Recension more tightly to the canonical narrative of the Bible.

It is noteworthy that the Third Recension envisaged a slightly different ending than its model. Indeed, while the First Recension quickly describes the final defeat of the Antichrist foreshadowing the consequences of Judgment Day, the Third Recension lingers over the enumeration of the apocalyptic events predicting Christ's Second Coming. It mentions droughts, famine, drying rivers and dying fish, the lack of people for burying the dead, accompanied by stench and filth everywhere. A further difference concerns the events after Christ's glorious coming. Whereas the First Recension mentions briefly the righteous shining in heaven and the sinners punished in hell, the Third Recension describes the final consumption of the world by fire, addressing as blessed those who will be prepared when these events take place.

To sum up, four main innovations distinguish the Third Recension. Firstly, the Ishmaelites of the First Recension are identified here with the Saracens. In contrast to the First Recension, their invasion is presented exclusively as a future event, which will foreshadow the Last Judgment. Secondly, there is no mention of the many apostasies on the part of the Christians after the Saracens' invasion, as detailed in chapter 12 of the First Recension. Thirdly, the king of the Romans, who will fight and defeat the Saracens in the Last Days, is a western ruler: he dwells in Rome and from there he will start his mission. Finally, the author of the Third Recension closes the work with a detailed description of the catastrophic events foreshadowing and following Judgment Day. The text's final address is of moral nature and consists of an exhortation to live righteously in this world in order to share the same glorious fate of the saints in the afterlife. These are all elements featuring repeatedly in the homiletic collection of $\boldsymbol{A}$, as we have seen, which ensure that the Third Recension fits perfectly well in that context.

\section{Conclusion [CGa]}

In this final assessment, it seems pertinent to re-visit once more the questions of how the redactor of the Third Recension of PsM worked and why he acted the way he did. The basis of the product that has come down to us was clearly the First Latin Recension and it will again be paramount to compare the redaction to the original.

It is very clear that one main driving-force behind the changes was the desire to create a text that would be more agreeable to a Latin Western audience entirely lacking any background in Syrian and especially Syriac literature. It seems obvious, for example, that the excurse on Medan and Persian history (chapters 7 and 8 in the First Recension) was dropped completely for this reason. On similar grounds, the earlier parts of the Revelationes were also brought into more accordance with estab- 
lished Biblical/Old Testament history. The text was also heavily abridged in these earlier sections to render it more readable. Changes were also made in the Second Latin Recension in very similar fashion, but the outcome was still quite different. Some intriguing features of PsM were actually kept by the redactor of the Third Recension. Jonitus, the fourth son of Noah, was even retained in the version transmitted by codices $\boldsymbol{A}$ and $\boldsymbol{K}$. He was, however, dropped from the text copied by Winithar. That is again not surprising for two reasons: firstly, Winithar can be described as an expert on the Bible and it is very probable that he adjusted the text himself. Secondly, the St Gall monk probably also knew the Second Latin Recension, a version that had likewise cut Jonitus. One has to admit though, that it cannot be ascertained whether Winithar already knew the First or the Second Recension at the time he was working on his text of the Third Recension.

A very interesting trait shared by the Second and Third Recensions is the assimilation or incorporation of the Christian anti-Saracen hero. Whereas the First Recension speaks of a rex Gregorum sive Romanorum and thereby clearly has the Byzantine Emperor in mind, the Second renders him rex Christianorum et Romanorum $^{115}$, while the Third has, as we have seen, the very peculiar, hyper-specific rex Romanorum de Roma. It is easy to see why a Latin redactor might have wanted to make that change. But the redactor of the Third Recension was even more rigorous in order to leave not a shread of doubt as to who was bound to act. This is even more remarkable when one takes into account that there was still no king or emperor of old, western Rome at the time of the text's production. It was thus very important for our writer to make that specific point and it fits with his overall interest in Roman history. Whereas nearly all passages in the first chapters of PsM were cut to a certain extent, the redactor provides us with a full version of chapter 9, an alternative history of early and pre-classical Rome, including a connection to Alexander the Great (d. 323 BCE). The next section that remained nearly uncut concerns the "second outing" of the Ishmaelites or Saracens. As we have seen, the "historical part" on a Saracen invasion in Roman times was indeed cut from the work, but the far longer pseudo-prophetical and prophetical part remained. This had the effect of binding the Saracens even closer to the narrative on the End Times than had hitherto been the case - an effect certainly intended by the redactor, who was keen on the connection between Romans, Saracens and the Last Judgment. When Winithar called his gentle redaction of the Third Recension De gentibus, he was clearly thinking of this part too. Conspicuously, the long passage on the misconduct and apostasy of Christians was cut from this section, which clearly shows that, in contrast to the First Recension, the outlook of this version of PsM was generally outwards and not on the own flock. This is also underlined by the strong interest in the Antichrist, who, despite all his mimicry, could and would have been seen as the absolute out-

115 Prinz, "Eine frühe abendländische Aktualisierung der lateinischen Übersetzung des PseudoMethodius," 14, with n. b. 
sider in the narrative. The message of this version of the text, far more so than in the First Recension, let alone in the Syriac original, was to prepare its readers for the things to come and not to make them adjust their life in the present. Still, that Last Judgment was to be expected in the not too distant future, given that the Saracens were already very present in the world of the redactor, which went to prove the accuracy of the prophecy.

The Third Recension of PsM also underlines a general trait of the text, regardless of which version one used: its multi-functionality. The Reichenau manuscript (A) used it as the last in series of sermons on the End Times, and Winithar (S) while clearly also keen on eschatology - rather as a fund of Roman and Saracen history. Finally, the Cologne manuscript (K) found that PsM answered some of the compilers' questions about the Book of Daniel. The multifaceted text could serve a purpose for all of them - and for more people, if we consider that the other recensions were put to an even greater variety of uses. All three copies of the Third Recension have one thing in common - and this is again a trait that we can tentatively generalise for PsM: in all cases, the text was consciously included to bring the picture the respective manuscript wished to present up to date. To a contemporary audience, its salient feature will probably have been the connection it made between the Saracens, the End Times and salvific history. PsM neatly provided support for the Book of Daniel narrative, it showed a unique vision of the Romans and Christians fighting the Saracens and it connected the very up-to-date fear of these adversaries with a compelling and dramatic vision of the Last Days. The Third Recension was, in a way, not unique in this respect. Its singularity lies in the attempt to render PsM agreeable to a Latin audience while trying to keep as many features of the original as possible. Still, it was not tailor-made for one purpose only, as we have seen, the redactor managed to keep much of the richness of the original version. Thus, it is rather not by chance that we see it used in different combinations with various other texts and genres: this versatility was, in fact, built into the work from the outset.

\section{Edition [CGr]}

\section{Editorial Principles}

The present edition of the Third Latin Recension of Pseudo-Methodius' Revelationes relies on the three known witnesses and on the critical edition of the First Recension. The following sigla will be used: 
Tab. 2

\begin{tabular}{|c|c|}
\hline $\bar{A}$ & $\begin{array}{l}\text { Karlsruhe, Badische Landesbibliothek, Augiensis Cod. perg. 254, fols. 204r-211r, saec. } \\
\text { VIII ex. / IX in., northern Italy or Switzerland. }\end{array}$ \\
\hline$A^{2}$ & Corrections to the original readings of $A$ by a later, perhaps tenth-century hand. \\
\hline$K$ & $\begin{array}{l}\text { Köln, Erzbischöfliche Diözesan- und Dombibliothek, Cod. 15, fols. } 84 \mathrm{v}-86 \mathrm{r} \text {, saec. IX, Ger- } \\
\text { many. }\end{array}$ \\
\hline$S$ & $\begin{array}{l}\text { St. Gallen, Stiftsbibliothek, Cod. 238, p. 385-392, saec. VIII', St Gall. Winithar's auto- } \\
\text { graph in its entirety. }\end{array}$ \\
\hline $\operatorname{Rec} .1$ & $\begin{array}{l}\text { Critical edition of the First Recension: W.J. Aerts and G.A.A. Kortekaas, eds., Die Apoka- } \\
\text { lypse des Pseudo-Methodius. Die ältesten griechischen und lateinischen Übersetzungen . } \\
\text { Vol. 569, Corpus Scriptorum Christianorum Orientalium, Subsidia } 97 \text { (Louvain: Éditions } \\
\text { Peeters, 1998). }\end{array}$ \\
\hline
\end{tabular}

The text transmitted by $A$ has been corrected in its initial part by a later hand, which normalises the grammar and, on one occasion, upgrades the abbreviation system to contemporary standards. At 1. 31/32, indeed, the corrector changes astralocus to astrologus and re-writes the abbreviation -us in the word magnus according to a form used from the late ninth century onwards. The text transmitted by $K$ features several omissions and errors. In two significant cases, $K$ shares the peculiar reading of $S$ (i.e. non estimabitur at 1. 131/132 and mulierem uirginem at 1. 148). In several other cases, however, the readings of $K$ are nearer to those of $A$ than to those of $S$, perhaps because the writer of $S$, i.e. Winithar, modified the text on his own initiative. I would therefore cautiously suggest the existence of two different branches in the textual transmission, one of which includes $S$ and $K$, without posing a direct dependence of $K$ on $S . S$, and probably Winithar himself, introduced several innovations compared to the other two witnesses. Many of them are additions which aim at linking the text to the Bible more closely.

This edition strives to reproduce as much as possible the peculiarities of the language of the known witnesses, correcting only when a corrupt reading can be explained as a possible mechanical and banal error. The readings of $A$ are preferred in the case of equally valid variants. The edition accommodates three apparatuses. The first records the biblical passages which are either explicitly quoted or alluded to in the text. The second contains references to the sources employed in the text. In addition, the references to those chapters of the First Recension which the Third abridges or adapts are placed in the right margin of the text. The third apparatus is an apparatus criticus. As a rule, it records only variant readings to the published text (negative principle). In the case of difficult or peculiar readings, however, the apparatus criticus does give account of their occurrence in the manuscripts (positive principle). The punctuation corresponds to modern conventions.

Orthography: Respecting modern editorial conventions, the edition uses $V$ for both capital $U$ and $V$, and $u$ for both lowercase $u$ and $v$. Abbreviations are silently expanded. I have not recorded the following common orthographic variations in the 
manuscripts: between $e$ and $i$, as in sterelem/sterilem; $c$ and $t$, as in cognatio/cognacio; app- and adp-or similar, as in apposuit/adposuit; $i$ and $y$, as in gigantes/gygantes; $x$ and cs, as in uxorem/ucsorem; $p h$ and $f$ as in propheta/profeta. Some nonClassical readings can be explained by this common interchange between letters, as, for example, discendit instead of the Classical descendit (1. 62). Since discendit is transmitted by both $A$ and $S$, and descendit only by $K$, I have retained discendit in the edition. The reading orribilis (1. 64) instead of the Classical (h)orribiles, can be explained by reason of the common interchange between $i / e$ and the usual omission of $h$. Since $A, K$ and the First Recension read orribilis, I have retained this form in the edition. Similarly, I have maintained the non-Classical iniuriosus (1. 22) for iniuriosos, since the ending $-u s$ for the accusative plural features in both $A$ and $K$ ( $S$ omits this passage).

The verbal form inchoat recurs three times at lines 37-38 in several orthographic variations, of which inquoad is the most often used in all three witnesses. Therefore, I chose to make the spelling uniform and always use inquoad in the edition. For the rare word asincitum, indicating a special sort of mineral bitumen, ${ }^{116}$ I have chosen the spelling arsincitum contained in $A$ (1. 88).

As for the diphthong -ae, it features in every possible variation (-ae, $-e$, or $e$ ) and without consistency, both within the same manuscript and between the three witnesses. I have mostly opted for normalisation. Thus, when the manuscripts disagree, I have silently put -ae regardless of the original text. In contrast, when all the witnesses share the same spelling, although not Classical, I have retained it in the edition. For instance, the edition features seculum (1. 11, 163, 200), but both caelo (1. 51) and celo (1. 117, 121, 199), according to the respective uniform readings of the manuscripts.

Worthy of particular mention are the numerals, which either appear in the form of Roman digits or were spelt out without any consistency across the three manuscripts. Only $K$ features, although seldom, ordinal numbers in the mixed form of a digit with a flexion suffix. The present edition features both cardinal and ordinal numbers in the form of Roman digits, without indicating possible flexion suffixes (e.g. XXX = both triginta and tricesimus, $-a,-u m$ ). ${ }^{117}$ The actual readings of the manuscripts, when discordant, are recorded in the apparatus.

I have capitalised all proper names silently. Proper names of persons and places are usually spelt in various forms both within the same manuscript and across the three witnesses. Provided the variants of a name were equally valid, I have chosen one of the spellings of $A$ and reproduced it consistently throughout the text, while recording the other readings in the apparatus. Otherwise, I have chosen the variant which best corresponds to the text of the model, be it the First Recension or Isidore

116 Asincitum recurs in the First Recension and in the Cosmographia 41b, 10 of Aethicus Ister, who drew on the Revelationes for this passage. See Aethicus Ister, Cosmography, ed. Herren, 52.

117 The only exception concerns secundum [...] tertium on 1. 109, which I have printed in full. 
of Seville's works. The list of the names of the "Unclean Nations" deserves special mention (1. 96-101): the spelling of their names varies considerably both from manuscript to manuscript and when compared to the First Recension. ${ }^{118}$ In particular, $S$ features a number of unique names (perhaps Winithar's own invention?). In this case, I have again preferred the readings of $A$, which stick more closely to the First Recension, and have recorded the variants in the apparatus. All three witnesses and the First Recension unanimously state that the "Unclean Nations" amounted to 22 (1. 101). However, both $A$ and the First Recension lists 23 names, perhaps because Gog and Magog were considered to be the same people. Conversely, both $S$ and $K$ omit a single name from their lists, the Agrimardii and the Arcnei respectively, whether because of a simple distraction or, having noticed the contradiction, on purpose.

Morphology: I have mostly retained the morphologic form of the witness(es), even when non-Classical, as for example in the case of: 1) quondam (1. 15) for the Classical quendam, transmitted both by $A$ (the other two witnesses omit it) and by the majority of the manuscripts of the First Recension; 2) filia (1. 58), transmitted by all three witnesses and by the First Recension instead of the expected filiam; 3) qui (1. 63), referred to mare (which does occur as masculine in the early Middle Ages), instead of the Classical quod; 4) exient (1. 93), as transmitted by both $A$ and $K$ and usual in Biblical Latin (see also exiet at 1.94). $S$ features the Classical form exibunt; 5) qui (1.140), referred in all three witnesses to gentes, instead of the Classical quae.

As for the construction terram Eonan, in quo solis ortus fit (1. 30-31), the anomalous in quo referred to terram is recorded in both $A$ and $K$ ( $S$ omits this passage) and in the First Recension. It can be explained as an original literal translation of the corresponding Greek adverb है $\theta \alpha$, which persisted evidently in the subsequent textual transmission. ${ }^{119}$ At 1.167 I have emended the transmitted forms exaltauerit and exaltaret to the correct exaltabitur, resting on the text of the First Recension. I believe the variants to have originated from different misreadings of the same abbreviated form.

Syntax: I have retained non-Classical constructions when attested either in all or in the majority of the witnesses, as, for instance, in the case of in ipsum resuscitauit Deus genus humanum (1. 16-17) instead of the Classical in ipso, or Contradicunt regnum Romanorum (1. 125) instead of the Classical contradicunt regno transmitted by the First Recension. This concerns also the non-Classical use of the personal pronoun eius instead of the possessive adjective suus, - - , - um; I have preserved, for instance, Kain et eius cognatio (1.18), as transmitted in the manuscripts. Furthermore, I have retained the non-Classical construction of dare with accusative of the receiv-

118 For this list of names in the Syriac, Greek and Latin versions of the Revelationes, see Sackur, "Einleitung: Pseudomethodius," 36-39.

119 On the First Latin Recension as translation verbum e verbo of the Greek model see Aerts and Kortekaas, “Einleitung: Die Apokalypse des Pseudo-Methodius,” 25. 
ing person and ablative of the given thing in the line: Dedit Noe Ionitum filium suum terra Eonan (1. 30), as transmitted by $K^{120}$

I have accepted the words ad edificandum turrem (1. 32-33), as transmitted by both $A$ and $K$ ( $S$ omits this passage), in place of the Classical ad edificandam turrem. Although either copyist, or their models, could easily have misread an original edificandam and written edificandum instead, I prefer to think of a non-Classical combination of $a d+$ gerund + accusative in this case, something which also occurs at 1 . 163-164 (ad arguendum perfidiam).

At 1. 169 I have maintained the irregular construction Tunc distruitur omnem principatum et potestatem, because I regard omnem principatum et potestatem as a literal quote from the Bible, which has not been adapted to the new syntactic context. We find further examples of non-Classical constructions at 1. 179, where the ablative replaces the expected accusative (sol in tenebris et luna in sanguine instead of sol in tenebras et luna in sanguinem), at 1. 186 (coram + acc. instead of abl.) and, finally, at 1. 188 (adherebunt + acc. instead of dat.). On both 1. 93 and 1. 140, I have accepted the faulty gentes illas and gentes illas pessimas instead of the correct nominative form. Both passages were written without the support of corresponding sentences in the First Recension and all witnesses agree, except in the case of the second occurrence, where $S$ features a different, and indeed correct, reading (illi pessimi).

Further peculiarities: The passage describing the genealogy of Shem (1. 3340), which parallels the account of Genesis and draws on Isidore's Etymologiae, is damaged: $S$ contains it only in its final part, while $A$ transmits the text with two lacunae and a repetition, and the readings of $K$ are often corrupt. Nevertheless, $K$ alone contains the words inde sunt Caldei iusti, which, following Isidore, must relate to Arfaxat. The adjective iusti, however, does not occur in Isidore and could be a gloss pertaining to Caldei of different origin and one added at this point by the copyist of $K$ himself or by his model. For instance, the Adnotatio libri Hiezechielis imperfecta by Haimo of Auxerre contains the explanation VIRI ERGO, id est Chaldei, IVSTI SVNT relating to Ezekiel 23:45. ${ }^{121}$ Therefore, I did not include iusti in the edition.

The passage predicting the future attack of the Saracens (1. 46-53) shows signs of being an unaccomplished adaptation of the corresponding section of the First Recension. The redactor of the Third Recension wanted to present the account of the Saracens' invasion as a prophecy about the Last Days, whereas the First Recension records the attack as something that both already happened in the past and would occur again in the future. Therefore, some of the past tenses of the model had to be changed to future tenses. The shared readings of the oldest witnesses of the Third Recension, i.e. of $A$ and $S$, show that the redactor only implemented this modifica-

120 For the construction "dare aliquem aliqua re (per analogiam ad donare)" see Mittellateinisches Wörterbuch, vol. 3: D-E, 901, 27.

121 Haimo of Auxerre, Adnotatio libri Hiezechielis imperfecta, ed. Gryson, 23-388, at 266, 1. 461. 
tion in part. Instead of ascenderunt, the Third Recension features the present ascendunt in novissimis diebus; then it introduces the future subicient, which is not present in the model. Yet the perfect tense dominati sunt of the First Recension remains unchanged in $A$ and $S$, whereas it is replaced by the future tense dominabuntur in the ninth-century $K$. Although it hampers the proper understanding of the passage, I have chosen to use dominati sunt in the edition, considering it to be a faulty reading, but one which might reproduce the wording of the original text of the Third Recension. The scribe of $K$ might have corrected this form to the corresponding future tense on his own initiative. Therefore, we should not regard dominati sunt as a conjunctive "error" between $A$ and $S$ against $K$.

The section dedicated to the description of the "Unclean Nations" (1. 64-74) is corrupt, both in the Third and in the corresponding passage of the First Recension. Indeed, the latter's translation of the Greek version resulted in problematic passages, which the copyists of the Third Recension either reproduced verbatim, probably not understanding their meaning, or tried to modify without success. For in-

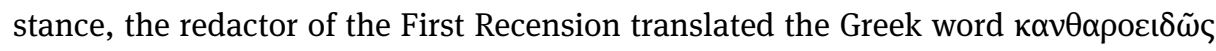
(Rec.1, 8, 4) with cantharo speciem, seemingly unconcerned by the resulting lack of sense. ${ }^{122}$ The Third Recension features the word cantharo (1. 67) in three slightly different spellings; I have printed the reading of $K$ which is the nearest to the text of the First Recension. Furthermore, the First Recension coined, it seems, the new Latin word spurcebilem, which each of the manuscripts of the Third Recension modified slightly. I have opted for the reading of $A$ (spurgiscibilem, 1. 68) in this case. In this passage, the manuscript $S$, perhaps Winithar himself, tried to normalise or correct those words, which were evidently perceived as difficult. The result is a section that is corrupted in new ways and which remains problematic. Except for one case, ${ }^{123}$ I have not strived to normalise these sentences nor to create a grammatically correct version of the text through conjectures and amendments, since I believe that no such correct version ever existed. On the contrary, I have retained, for instance, the participle coaculati for the correct coagulata, as well as the nominative producta conpago instead of the corresponding accusative productam conpaginem, which would have matched the syntactic structure. The reading lineamenta of the Third Recension (1. 70) could solve the crux desperationis inserted by the editors into the corresponding passage of the First Recension. ${ }^{124}$

Similarly complicated is the passage abridging chapter 9 of the First Recension, which comes back to the purpose of explaining how Chouset's progeny bound the Ethiopian, Macedonian, Roman and Greek peoples together to form a single family. The redactor of the Third Recension aimed to reproduce the information of his model very concisely. As a result, the reader can only understand the contents of

122 See Jerome, Commentarii in prophetas minores. In Abacuc, ed. Adriaen, 1. 2, 1. 409: scarabeus uel cantharus uermis est stercoris.

123 I have integrated a $<$ quae $>$ at 1.70.

124 See Aerts and Kortekaas, “Einleitung: Die Apokalypse des Pseudo-Methodius,” 111, 5. 
this section by bearing in mind the larger account of the First Recension. To establish the text of the edition was a difficult task. I interpret the uncertain and problematic reading semen (1.103) as "progeny": it occurs in this sense in the First Recension at ch. 9.7, as I have recorded in the apparatus fontium. I have maintained the flawed quod est (1. 108), which can be explained as an original misreading of the quidem of the First Recension, which is still recorded in $K$. As for the name of the city of Byzantium, I have reproduced the inconsistency of both $A$ and $K$ and of the First Recension regarding the forms Bizancia and Biza, although $S$ reads always Bizancia. On 1. 113 we have to suppose a loss of text in the First Recension, which persisted in all the known witnesses of the Third. Following the suggestion of the editors of the First Recension, ${ }^{125}$ the lacuna could be filled by adding <et Graecorum regnum >. I preferred, however, to simply mark the damaged passage without suggesting integrations for which I did not have enough evidence to rely upon. The following sentence (unde erit [...] Sarracinos, 1. 113-115) is an innovation of the Third Recension. A similar addition to the text of the First Recension occurs at 1. 165-166, again in regard to Chouset's progeny.

A further difficult passage is found at 1. 131-134, which I render as follows in the edition: et non estimabitur ut uel quis Christianus remaneat, quia in ecclesiis ibi fornicantur et faciunt uniuersa blasphemia in Christo. I interpret this to mean: "and even the surviving Christians will not be considered as Christians, since they commit fornication and every kind of blasphemy towards Christ there in the churches". The First Recension does not contain this passage. The problematic clause ut uel quis is transmitted only in $A$; $K$ reads aut uel quis; $S$ places ut before non estimabitur instead of et. Furthermore, $A$ alone reads pręstinabitur (= "will be bought") instead of non estimabitur. Praestinare is a rare verb, used mostly in Antiquity, which nevertheless occurs in lexicographic tools circulating widely in the early Middle Ages. ${ }^{126}$ Its presence in the sentence could hardly be explained as a misreading of an original non estimabitur, but must be regarded as a variant reading. I prefer to print non estimabitur for the moment, hoping for new witnesses of the Third Recension to be discovered.

Concerning the Antichrist (1. 146-147), both $K$ and $S$ introduce a remarkable innovation compared to both the other Recensions and to the text transmitted by $A$. Indeed, they present the mother of the Antichrist as a virgin: $S$, p. 390, reads nascitur de tribu Dan ex muliere uirgine; $K$, f. 85v, reads nascitur autem de tribu Dan mulierem uirginem. A, f. 209r, reads instead nascitur autem de tribu Dan ex muliere

125 See Aerts and Kortekaas, "Einleitung: Die Apokalypse des Pseudo-Methodius," 123.

126 See the digital edition of the Liber Glossarum under prestinare (http://liber-glossarum.humanum.fr/context.html?id-l=PR982, accessed 4 February, 2018) and also Sextus Pompeius Festus, De verborum significatu quae supersunt cum Pauli epitome, ed. Lindsay, 249, 27-28: Praestinare apud Plautum praeemere est, id est emendo tenere. 
et uir (which becomes uir<o $>$ in my edition). ${ }^{127}$ By reading muliere $(m)$ uirgine $(m)$, the branch of the transmission including $K$ and $S$ conforms with an alternative depiction of the birth of the Antichrist which circulated since Late Antiquity - for instance, in the work of the Church Father Jerome - and was expressly declared as faulty by Adso of Montier-en-Der in the tenth century. ${ }^{128}$ Since $A$ shares the reading ex muliere et uir $<0>$ with both the First and Second Latin Recensions and with the corresponding passage of the Greek version, I regard ex muliere uirgine as a modification of the original reading. Therefore, my edition reproduces the text of $A$.

\section{Symbols and abbreviations used in the edition}

Tab. 3

\begin{tabular}{|c|c|c|c|}
\hline \multirow[t]{2}{*}{ Symbols: } & $\langle\ldots\rangle$ & $=$ & words not occurring in the manuscripts and added by me \\
\hline & $\star \star \star$ & $=$ & lacuna in the text \\
\hline \multirow[t]{8}{*}{ Abbreviations: } & a.c. & $=$ & $\begin{array}{l}\text { ante correctionem (referred to a correction done by the copyist him- } \\
\text { self) }\end{array}$ \\
\hline & p.c. & $=$ & $\begin{array}{l}\text { post correctionem (referred to a correction done by the copyist him- } \\
\text { self) }\end{array}$ \\
\hline & add. & $=$ & addidit \\
\hline & praem. & $=$ & praemisit \\
\hline & scr. & $=$ & scripsit \\
\hline & sup.l. & $=$ & supra lineam \\
\hline & tr. & $=$ & transposuit (when a copyist inverts the succession of two words) \\
\hline & ut uid. & $=$ & ut videtur \\
\hline
\end{tabular}

\section{Sources mentioned in the Apparatus Fontium}

The sources listed below were used by the redactor of the Third Recension only. They do not occur in the First Recension.

127 Cf. the corresponding passage in the First Recension: Ingredietur enim hic filius perditiones in Hierusolimam et sedibit in templo Dei sicut Deus, homo cum sit carnalis ex semini uiri et ex utero mulieres, de tribu Dan discendens (Aerts and Kortekaas, "Einleitung: Die Apokalypse des PseudoMethodius," 195, 1-3). The Second Recension reads: Ingredietur autem in Hierusolimam et sedebit in templo Dei, putat se quasi ut Deus sit et erit exaltatum cor eius nimis, cum <sit> homo ex semine uiri filius mulieris de tribu Dan (Prinz, "Eine frühe abendländische Aktualisierung der lateinischen Übersetzung des Pseudo-Methodius,” 222-224).

128 See Adso of Montier-en-Der, De ortu et tempore Antichristi, ed. Verhelst, 24: Nascetur autem ex patris et matris copulatione, sicut et alii homines, non, ut quidam dicunt, de sola uirgine. For PseudoHippolytus' and Jerome's depiction of the birth of the Antichrist from a virgin see McGinn, Antichrist, 74-75, with nn. 67 and 75. 
ISID., ChRON. = ISIDORUS HISPALENSIS, Chronica - ed. José Carlos Martín, CCSL 112 (Turnhout: Brepols Publishers, 2003), 4-208.

ISID., Etym. = ISIDORUS HISPALENSIS, Etymologiarum sive Originum libri XX - ed. Wallace Martin Lindsay (Oxford: Oxford University Press, 1911). 